\title{
Asymmetric syntheses of functionalized pyrrolizidin-3-ones
}

\author{
Christine Thomassigny, Géraldine Le Bouc, and Christine Greck* \\ LV-UMR CNRS 8180, Université de Versailles-St-Quentin en Yvelines, \\ 45, avenue des Etats-Unis, 78035 Versailles Cedex, France \\ E-mail: greck@chimie.uvsq.fr
}

DOI: $\underline{\text { http://dx.doi.org/10.3998/ark.5550190.0013.821 }}$

\begin{abstract}
The syntheses of 1- and 7-hydroxypyrrolizidin-3-ones are described via asymmetric catalytic hydrogenation or diastereoselective reduction of ketones as key steps. 2,7-Disubstituted pyrrolizidin-3-ones are also prepared. The second chiral center is created using stereoselective electrophilic amination or hydroxylation reactions.
\end{abstract}

Keywords: Pyrrolizidinones, asymmetric synthesis, amination, hydroxylation, hydrogenation

\section{Introduction}

Functionalized bicyclic lactams with the nitrogen atom at the bridgehead position are interesting structures well studied in the literature. One commonly encountered function of this skeleton is in the formation of rigid dipeptide mimics. ${ }^{1}$ Moreover, these bicyclic systems are known to be effective intermediates in the preparation of alkaloids such as the polyhydroxylated pyrrolizidines or indolizidines, ${ }^{2-4}$ and of more complex structures like lepadiformine ${ }^{5}$ or furopyrrolizidinone. ${ }^{6}$ The synthesis of pyrrolizidin-3-ones mono- or disubstituted at positions 1 or 7 was reviewed in $2000 .^{7}$

We have been interested in the preparation of such systems, in particular the $(1 R, 7 \mathrm{a} S)$ - and $(1 S, 7 \mathrm{a} S)$-1-hydroxypyrrolizidin-3-ones (1 and $\mathbf{2})$ on one hand, and in a second line of study the $O$-protected (7S,7aS)- and (7R,7aS)-7-hydroxypyrrolizidin-3-ones (3 and 4) (Figure 1).
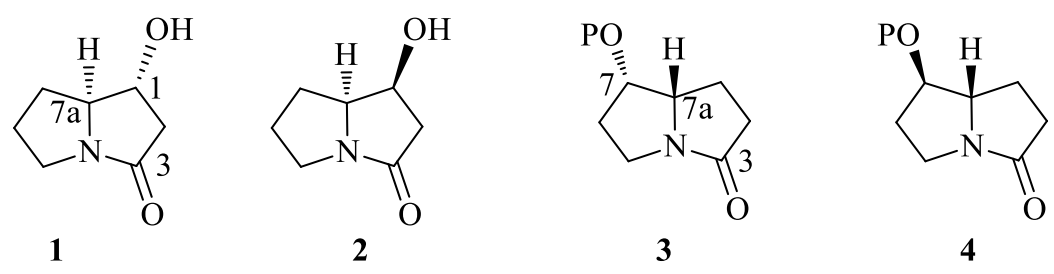

Figure 1. 1- and 7-Oxy-substituted pyrrolizidin-3-ones 1-4. 
The preparations of the bicyclic lactams $\mathbf{1}$ and $\mathbf{2}$ and their enantiomers have been detailed in the literature. ${ }^{8-17}$ Most of the reported syntheses started from the amino acid proline or its derivatives, as these substrates have the advantage of introducing directly the stereocenter at $\mathrm{C}-7 \mathrm{a}$ of the ring system. The center at $\mathrm{C}-1$ was controlled by asymmetric synthesis, by formation of a $\beta$-hydroxyester or amide and subsequent cyclisation under basic conditions, by aldol condensation or by reduction of pyrrolizidine-1,3-dione leading to $\mathbf{1}$ as a major product ( $90 \%$ d.e.). Other methods for the preparation of $\mathbf{2}$ have been described, such as the catalytic hydrogenation of 1,2-dihydro-1-hydroxypyrrolizin-3-one or pyrrolizine-1,3-dione. From all these preparations, the overall yields are quite often low due to multistep syntheses, with d.e. from 60 to $99 \%$ for $\mathbf{1}$, and up to $99 \%$ for $\mathbf{2}$.

Concerning the 7-hydroxypyrrolizidinones $\mathbf{3}$ and $\mathbf{4}$, few examples of synthesis are reported in the literature. ${ }^{4,18,19}$ In particular, the lactam $\mathbf{3}$ is described as an intermediate in the preparation of (-)-supidine, ${ }^{18}$ whereas its $7 \mathrm{a}$-epimer led to 1 -hydroxypyrrolizidine. ${ }^{4}$

We present in this manuscript a new route to the bicyclic compounds $\mathbf{1}$ and $\mathbf{2}$ from L-proline and of $\mathbf{3}$ and $\mathbf{4}$ from L-pyroglutamic acid (PGA) based on diastereoselective reduction or catalytic hydrogenation.

Then we extended the pool to 2,7-difunctionalized pyrrolizidin-3-ones (Figure 2). In the literature, one example of the preparation of the protected dihydroxylated compound is reported, by tandem cycloaddition of nitroalkene. ${ }^{19 \mathrm{~b}}$ In our approach, the chiral center at C-2 is created by electrophilic hydroxylation or amination reactions.

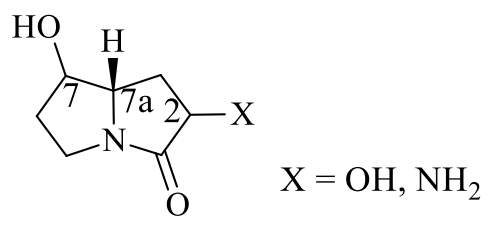

Figure 2. 2,7-Difunctionalized pyrrolizidin-3-ones.

\section{Results and Discussion}

We prepared the methyl $\beta$-ketoester 6 by the method of Masamune ${ }^{20}$ from the commercial $N$-Boc L-proline 5, in good yield (88\%) without epimerization at chiral center (Scheme 1). The deprotection of the carbamate using trifluoroacetic acid (TFA) gave 7, which was purified and reduced using sodium borohydride $\left(\mathrm{NaBH}_{4}\right)$. This reaction led to two separable diastereoisomers whose NMR spectra are in accord with the hydroxypyrrolizidinone structures $\mathbf{1}$ and $\mathbf{2}$, with predominance of the first. After 2 hours at $25{ }^{\circ} \mathrm{C}$, with $1.2 \mathrm{~mol} \%$ of $\mathrm{NaBH}_{4}$, the compounds 1 and 2 were obtained in a $54 / 46$ ratio and $81 \%$ yield. By decreasing the temperature to $-10{ }^{\circ} \mathrm{C}$ and with a slow addition of $0.6 \mathrm{~mol} \%$ of $\mathrm{NaBH}_{4}$, we managed to upgrade the diastereoisomeric ratio to $85 / 15$, although in lower yield (67\%). The 1-hydroxypyrrolizidin-3-one 1 was isolated in 57\% 
yield from 7 after separation by chromatography over silica gel. The formation of the bicyclic compounds could proceed by reduction of the ketone and subsequent cyclisation. The formation of $\mathbf{1}$ would then be in agreement with a chelated transition state for the reduction step.

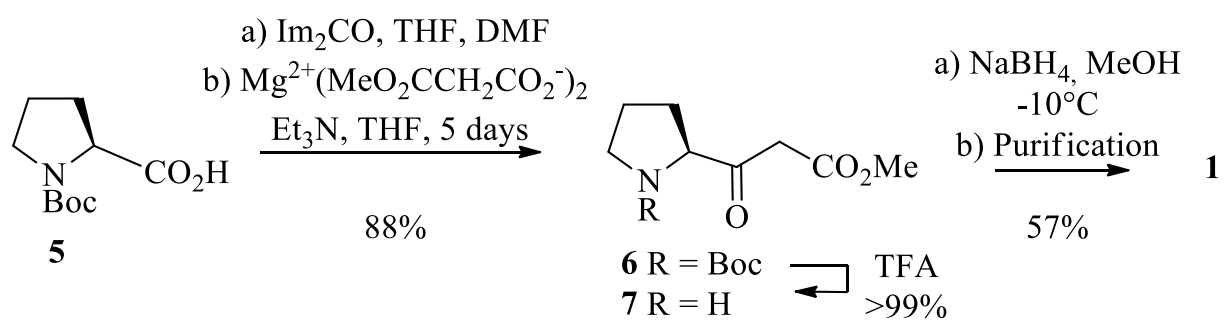

Scheme 1. Formation of the (1R,7aS)-1-hydroxypyrrolizidin-3-one 1.

The bicyclic compound $\mathbf{2}$ was obtained from the $\beta$-ketoester $\mathbf{6}$ following a similar way to that described by Genêt ${ }^{10}$ for the preparation of ent-2 from D-proline. We first performed a classical reduction of 6 with $\mathrm{NaBH}_{4}$ to give the $\beta$-hydroxy-esters 8 and 9 in a 56/44 ratio and in $81 \%$ yield (Table 1, scheme 2). Physical separation of the two epimers by silica gel chromatography led to the two references for HPLC analysis. The hydrogenation of $\mathbf{6}$ run in the presence of $[(R)$ BinapRu] $\mathrm{Br}_{2}$ as catalyst at $50{ }^{\circ} \mathrm{C}$ led to $\mathbf{8}$ in yields of up to $97 \%$ and d.e. of $96 \%$ depending on the pressure and reaction time. The use of $\left[(S)\right.$-BinapRu $\mathrm{Br}_{2}$ as catalyst for the hydrogenation of $\mathbf{6}$ was not very efficient, the best ratio $\mathbf{8 / 9}$ being $16 / 84$.

Table 1. Formation of 8 and 9 from 6

\begin{tabular}{lccc}
\hline Conditions & $\begin{array}{c}\text { Pressure } \\
\text { (bars) }\end{array}$ & $\begin{array}{c}\text { Yield } \\
(\%)\end{array}$ & $\mathbf{8 / 9}$ \\
\hline $\mathrm{NaBH}_{4}, \mathrm{MeOH}, \mathrm{RT}, 2 \mathrm{~h}$ & 1 & 81 & $56 / 44$ \\
$\mathrm{H}_{2},[(R)-\mathrm{BinapRu}] \mathrm{Br}_{2}, 2 \mathrm{~mol} \%, 50{ }^{\circ} \mathrm{C}, 24 \mathrm{~h}$ & 1 & 92 & $98 / 2$ \\
$\mathrm{H}_{2},[(R)-\mathrm{BinapRu}] \mathrm{Br}_{2}, 2 \mathrm{~mol} \%, 50{ }^{\circ} \mathrm{C}, 48 \mathrm{~h}$ & 100 & 97 & $98 / 2$ \\
$\mathrm{H}_{2},\left[(S)-\mathrm{BinapRu} \mathrm{Br}_{2}, 2 \mathrm{~mol} \%, 50{ }^{\circ} \mathrm{C}, 48 \mathrm{~h}\right.$ & 1 & 33 & $16 / 84$ \\
$\mathrm{H}_{2},[(S)-\mathrm{BinapRu}] \mathrm{Br}_{2}, 2 \mathrm{~mol} \%, 50{ }^{\circ} \mathrm{C}, 24 \mathrm{~h}$ & 100 & 33 & $41 / 59$ \\
\hline
\end{tabular}

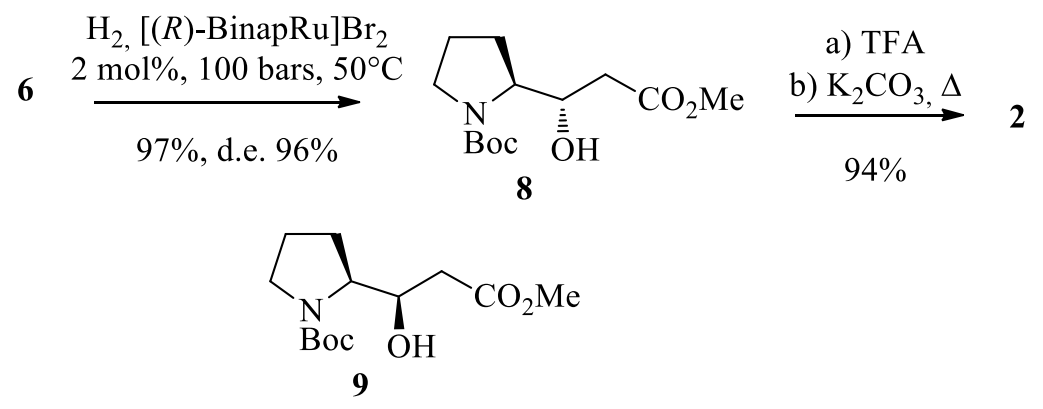

Scheme 2. Formation of the (1S,7aS)-1-hydroxypyrrolizidin-3-one $\mathbf{2}$. 
After treatment of $\mathbf{8}$ with TFA, the intermediate pyrrolidine was treated with potassium carbonate to give the expected (1S)-hydroxypyrrolizidin-3-one 2 (94\% for the 2 steps) (Scheme 2).

We reported few years ago the catalytic hydrogenation of $\beta$-ketoesters bearing a $\gamma$-lactam moiety. ${ }^{21}$ The full syntheses of $\mathbf{3}$ and $\mathbf{4}$ from commercial pyroglutamic acid $\mathbf{1 0}$ are detailed next. They began with the formation of the $N$-Boc protected $\mathbf{1 1}$ in three steps as described in the literature $^{22}$ (Scheme 3). The homologation using Masamune's method led to the expected $\beta$ ketoester 12 in $67 \%$ yield after 4 days of reaction. In the earlier communication we reported the catalytic hydrogenation of $\mathbf{1 2}$ and showed that the best conditions for obtaining the $\beta$ hydroxyester 13 or its diastereoisomer 14 selectively was to use the catalyst under atmospheric pressure at $55{ }^{\circ} \mathrm{C}$ for 40 hours. We observed the removal of the tert-butoxycarbamate protecting group concomitantly with the hydrogenation reaction under these conditions. The $\beta$-hydroxyester with the $3 S$ configuration (13) can be obtained in $94 \%$ diastereomeric excess and in nearly quantitative yield by using the $\left[(R)-\mathrm{BinapRu}_{\mathrm{B}} \mathrm{Br}_{2}\right.$ complex. The use of the $(S)$-catalyst led to the epimer $3 R \mathbf{1 4}$ as the sole isomer, also in good yield (89\%).

a) $\operatorname{Im}_{2} \mathrm{CO}$, THF, DMF

b) $\mathrm{Mg}^{2+}\left(\mathrm{MeO}_{2} \mathrm{CCH}_{2} \mathrm{CO}_{2}^{-}\right)_{2}$<smiles>O=C1CCC(C(=O)O)N1</smiles>

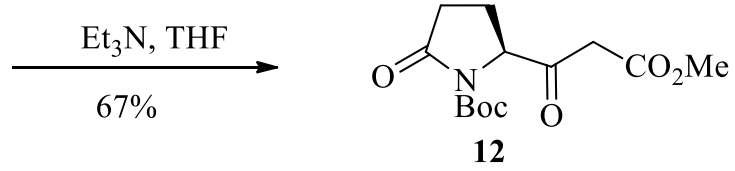
$\mathrm{H}_{2,},[(R)-\mathrm{BinapRu}] \mathrm{Br}_{2}$
$\mathrm{MeOH}, \mathrm{Patm}, 55^{\circ} \mathrm{C}$
$97 \%$, d.e. $94 \%$<smiles>CC(=O)C[C@H](O)[C@H]1CCC(=O)N1</smiles>

13

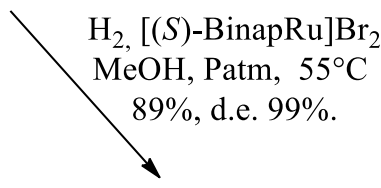<smiles>CC(=O)CC[C@@H](O)[C@H]1CCC(=O)N1</smiles>

14

Scheme 3. Formation of the $\beta$-hydroxyesters 13 and 14.

The transformation of $\mathbf{1 3}$ and 14, respectively, into the epimeric pyrrolizidinones $\mathbf{3}$ and $\mathbf{4}$ was effected through the sequences described below (Scheme 4). After protection of the hydroxy functions as tert-butyldimethylsilyl ethers (15: 75\%, 17: 88\%), a first assay of the selective reduction of the methyl ester group with calcium borohydride formed in situ led to $\mathbf{1 6}$ and $\mathbf{1 8}$ in yields of 81 and $69 \%$ respectively. The yields were improved by reaction of 15 and 17 with a large excess of sodium borohydride (15 equiv.) in methanol, giving the same products 16 or 18 in yields of 94 and $77 \%$. Their cyclisation was previously performed in a short sequence: 
mesylation of the primary alcohol function, and cyclisation in the presence of potassium carbonate, leading to the pyrrolizidinones 3 and $\mathbf{4}$ in yields of around $60 \%{ }^{21}$ The yields have now been increased by the use of sodium hydride in tetrahydrofuran, becoming 84 and $85 \%$ respectively for the two-step sequence.

13

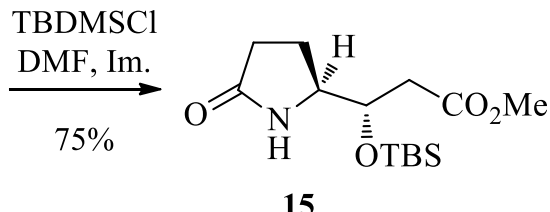

15

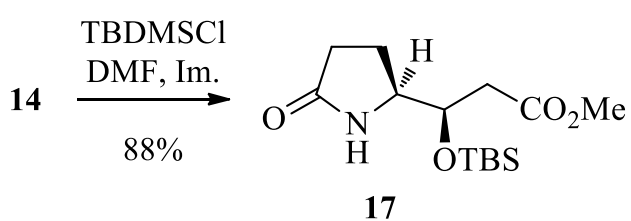

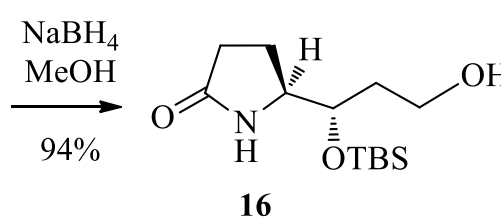

16

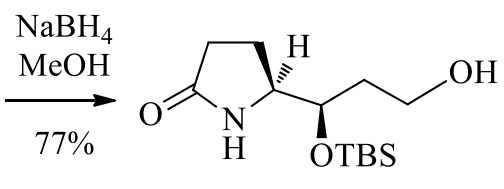

18 a) $\mathrm{MsCl}$

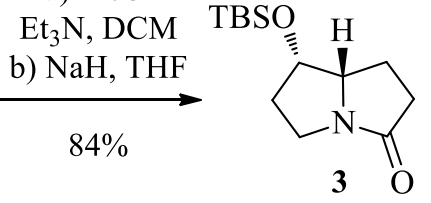

a) $\mathrm{MsCl}$

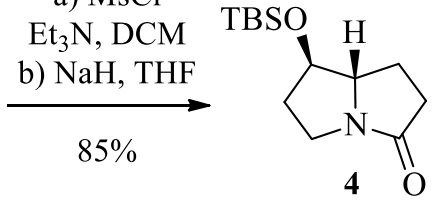

Scheme 4. Formation of the protected 7-hydroxypyrrolizidin-3-ones 3 and 4.

We have shown access to the monohydroxylated pyrrolizidin-3-ones 1-4 in d.e. of up to $99 \%$. For the two pyrrolizidinones $\mathbf{1}$ and $\mathbf{2}$ prepared in three and four steps respectively from $\mathbf{5}$, the diastereoselectivity is analogous to previously reported values, and is particularly remarkable for 2 (d.e. 96\%, overall yield 80\%) via a catalytic hydrogenation. Nevertheless, the very short synthesis described for compound 1 (d.e. 70\%) via low temperature reduction made this a particularly interesting and inexpensive scheme despite the moderate overall yield (50\%). Finally, the (7S,7aS)-7-(tert-butyldimethylsilyloxy)pyrrolizidin-3-one (3) and its epimer $(7 R, 7 \mathrm{a} S)-4$ were reached in nine steps from PGA (10) in overall yields of $30 \%$ and $27 \%$ respectively and excellent diastereoselectivities.

In a second project our aims were the 2,7-disubstituted derivatives 2,7-dihydroxypyrrolizidin-3-one and 2-amino-7-hydroxypyrrolizidin-3-one. The new functionality at position 2 was introduced at the beginning of the synthesis. We tested firstly the amination and hydroxylation reactions of PGA (10).

Beside the preparations of 3-amino $\gamma$-lactam described in the literature, ${ }^{23-25}$ there are very few instances of the direct amination $\alpha$ to the carbonyl of PGA. These last syntheses were based mainly on the reaction of the corresponding enolate with diphenylphosphoryl azide, ${ }^{24}$ or the hydrogenation of the oxime formed by the action of Bredereck's reagent followed by nitrous acid treatment. ${ }^{25}$ In these two cases the relative configuration of the amino-PGA in the major product was always cis. We have developed a way of direct amination of protected PGA leading to the trans configuration in the product. The Boc-protected methyl pyroglutamate $\mathbf{1 9}^{26}$ was treated with 1.1 equivalents of LiHMDS at $-78{ }^{\circ} \mathrm{C}$ for 1 hour, followed by addition of 2.0 equivalents of dibenzyl azodiformate (DBAD) in tetrahydrofuran at $-60{ }^{\circ} \mathrm{C}$ (scheme 5). After purification, the expected hydrazino derivative $\mathbf{2 0}$ was obtained in $66 \%$ yield, as only one diastereomer 
(d.e.>95\%, measured by NMR). The stereochemistry of the newly formed center of $\mathbf{2 0}$ was elucidated by conversion into the corresponding amine by a three-step sequence, namely, classical hydrogenation using $\mathrm{Pd} / \mathrm{C}$ followed by the addition of Raney nickel in the reaction mixture, then by cleavage of the tert-butoxycarbonyl protecting group with TFA, leading to 21 . The NMR spectral data of the product were in concordance with the structure of $\mathbf{2 1}$, and the trans configuration was proved by NOESY correlation studies. In particular, we found a strong effect between the protons $\mathrm{H}-4$ and $\mathrm{H}-3 \mathrm{~b}$, and also between $\mathrm{H}-2, \mathrm{H}-3 \mathrm{a}$ and $\mathrm{NH}_{2}$. There is clearly no effect between $\mathrm{H}-2$ and $\mathrm{H}-4$. All these results are in agreement with the $(R)$ configuration of the newly formed aminated stereocenter, showing that the enolate was attacked by the azodicarboxylate at its less hindered side only, leading to the one diastereoisomer. This result was particularly interesting in being the first example of direct amination of a protected PGA leading to the corresponding derivative with the trans configuration.

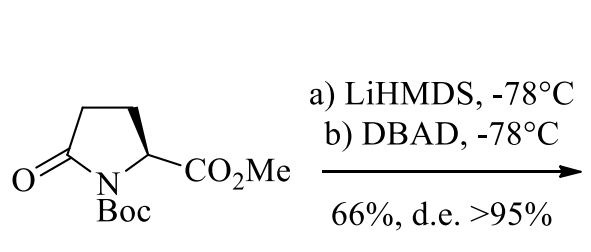

19

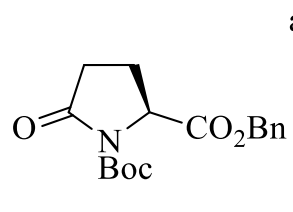

22

a) $\mathrm{LiHMDS},-78^{\circ} \mathrm{C}$

b) $\mathrm{TPO},-78^{\circ} \mathrm{C}$

c) $\mathrm{H}_{2} \mathrm{O}, \mathrm{CSA}$

$55 \%$

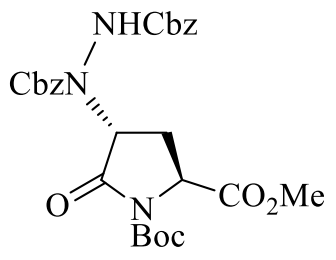

20

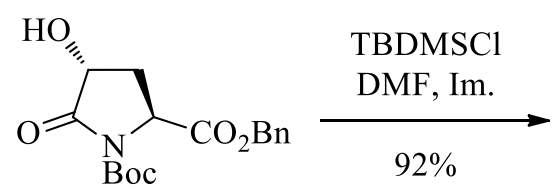

23

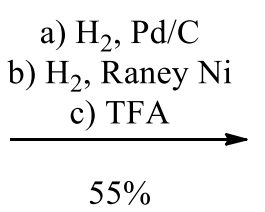

Scheme 5. Electrophilic amination and hydroxylation of protected PGA.

The electrophilic hydroxylation of the enolate of $\mathbf{2 2}^{22}$ by 3-phenyl- $N$-p-toluenesulfonyloxaziridine (TPO) has been first described by Nozoe $^{27}$ and completed by Young ${ }^{28}$. The reaction led to the hydroxylated 23 with a d.e. $>99 \%$ but in low yield (30\%). We increased this yield to $55 \%$ by the action of TPO at $-78{ }^{\circ} \mathrm{C}$ over 45 minutes followed by hydrolysis in the presence of camphorsulfonic acid (CSA) (Scheme 5). The d.e. was as good as those of the earlier authors, as only the trans isomer was obtained (d.e. $>95 \%$, measured by NMR studies). The newly-formed hydroxyl function was protected as a tert-butyldimethylsilyl ether under classical conditions to give $24(92 \%)$.

Thus, the 3-amino- and 3-hydroxy-APG have been prepared with excellent d.e. and in short preparative sequences. The fully-protected hydroxy compound $\mathbf{2 4}$ was used in the synthesis of 2,7-dihydroxypyrrolizidin-3-ones (Scheme 6).

To perform the synthesis of 2,7-dihydroxypyrrolizidin-3-ones, the carboxylic acid was first restored by hydrogenolysis of the benzyl ester of $\mathbf{2 4}$ and the subsequent homologation led to the 
$\beta$-ketoester 25 (75\% in two steps). The best results for the catalytic hydrogenation of the $\beta$ ketoester were obtained with the $N$ - and $O$-free compound 27, from successive treatment of 25 with tetrabutylammonium fluoride giving 26, then trifluoroacetic acid. The hydrogenation of 27 was performed at $55{ }^{\circ} \mathrm{C}$ and atmospheric pressure in the presence of $2 \%$ mol of $[(R)$ BinapRu $] \mathrm{Br}_{2}$ or $\left[(S)\right.$-BinapRu] $\mathrm{Br}_{2}$ catalyst. It gave the $\beta$-hydroxyesters $\mathbf{2 8}$ and $\mathbf{2 9}$ respectively with comparable diastereoselectivities and yields of $98 \%$ and $82 \%$.

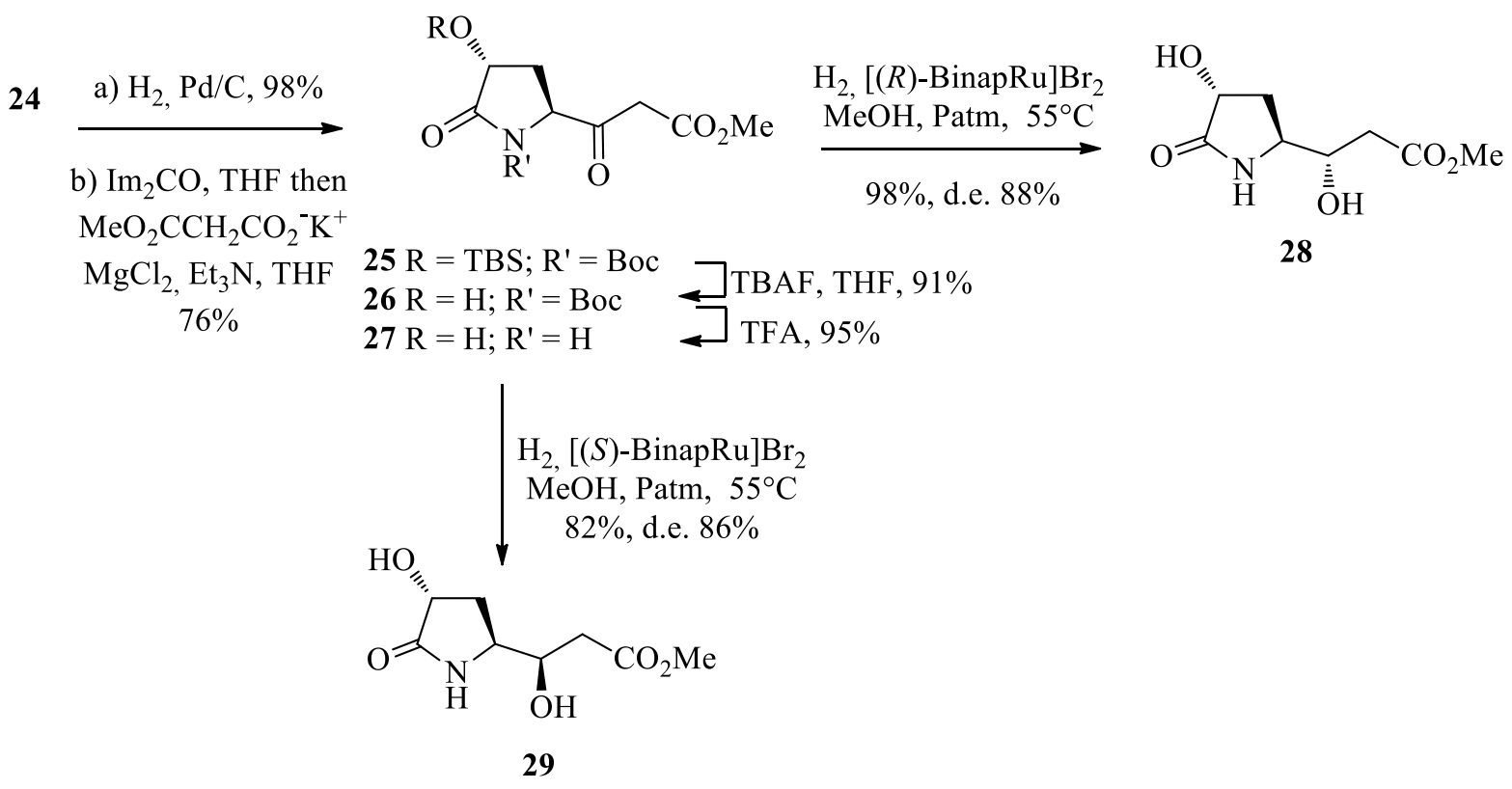

Scheme 6. Formation of the $\beta$-hydroxyesters 28 and 29.

The diol 28 was transformed into the corresponding bicyclic system $\mathbf{3 1}$ in four steps (Scheme 7). Regioselective silylation of $\mathbf{2 8}$ using triisopropylsilyl chloride in a mixture DMF/imidazole led to the intermediate 3'-triisopropylsilyloxy compound. The methyl ester was then reduced by the action of an excess of $\mathrm{NaBH}_{4}$, leading to 30. The primary alcohol was selectively tosylated and a cyclisation under basic conditions gave the pyrrolizidinone $\mathbf{3 1}$ with a yield of $43 \%$ for the 2 steps. The same sequence applied to $\mathbf{2 9}$ led to the compound $\mathbf{3 3}$ with a yield of $18 \%$ for the 4 steps.

A similar synthetic way is actually under progress for the obtaining of 2-amino-7hydroxypyrrolizidin-3-one.

Finally, we tested the functionalization in $\alpha$ of the carbonyl of the pyrrolizidinones $\mathbf{1}, \mathbf{2}, \mathbf{3}$ and 4 in the way to increase our pool of disubstituted pyrrolizidin-3-ones. The functionalization of the derivatives $\mathbf{1}, \mathbf{2}$ and $\mathbf{3}$ by electrophilic amination or hydroxylation failed. Only $\mathbf{4}$ led to the hydrazine 34 (Scheme 8) with the yield of 63\% using strong conditions: 5.0 equivalents of LDA, then the addition of a solution containing 4.0 equivalents of DTBAD at $-60{ }^{\circ} \mathrm{C}$. In term of diastereoselectivity for $\mathbf{3 4}$, NOESY correlation studies showed that the irradiation of the proton 
$\mathrm{H}-2$ induced an effect at the proton $\mathrm{H}-7 \mathrm{a}$, which is in favour of a cis relation. When the proton $\mathrm{H}-$ 7 was irradiated, no effect with the H-2 was observed that confirmed a $2 S$ absolute configuration of the new asymmetric aminated center.
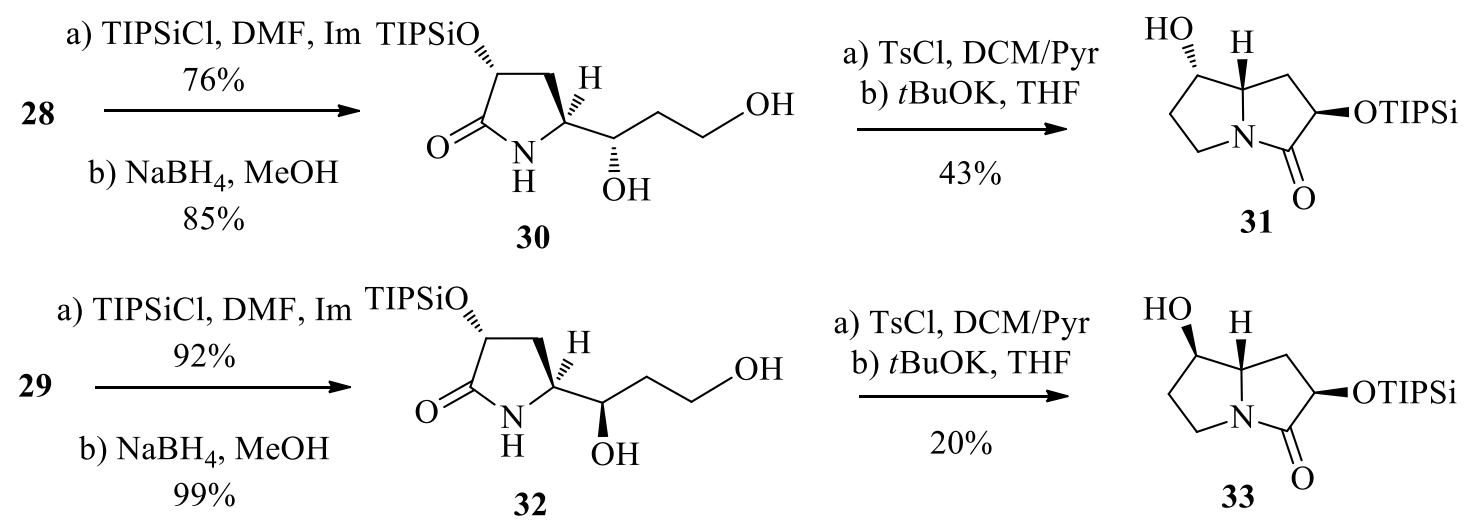

Scheme 7. Formation of the 2,7-dihydroxypyrrolizidin-3-ones $\mathbf{3 1}$ and $\mathbf{3 3 .}$

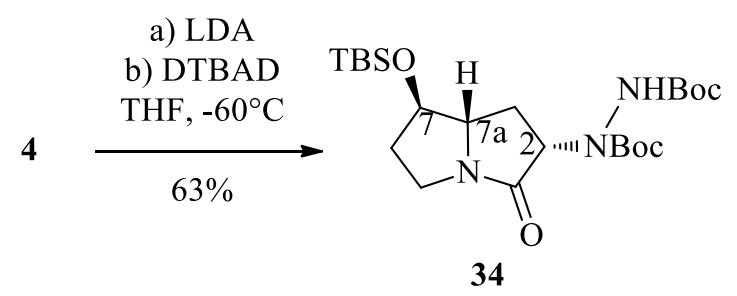

Scheme 8. Formation of 34 .

\section{Conclusions}

In conclusion, we report the synthesis of seven mono- and di-substituted pyrrolizidin-3-ones from L-proline or L-pyroglutamic acid. Starting from L-proline, a very short synthetic sequence was developed to reach $\mathbf{1}$. Treatment of the $\beta$-ketoester derived from L-proline with sodium borohydride resulted in a one pot reduction/cyclisation. The hydroxypyrrolizidin-3-ones $\mathbf{2}, \mathbf{3}$ and 4 were obtained using asymmetric catalytic hydrogenation as the key step.

2,7-Disubstituted pyrrolizidin-3-ones were synthesized from L-pyroglutamic acid. The chiral centers were created at C-2 by electrophilic amination or hydroxylation and at C-7 by catalytic hydrogenation as before. The two stereomeric 2,7-dihydroxypyrrolizidin-3-ones $\mathbf{3 1}$ and $\mathbf{3 3}$ were prepared by this way. The $N, O$-diprotected 2-hydrazino-7-hydroxypyrrolizidin-3-one 34 was obtained by direct electrophilic amination of the corresponding 7-hydroxypyrrolizidin-3-one 4 . Electrophilic amination of $N$-Boc PGA methyl ester was also performed, leading exclusively to 
the 3-amino-PGA methyl ester 21 with a trans relative configuration, which should be an attractive building block for organic synthesis.

\section{Experimental Section}

General. Solvents were distilled according to Purification of Laboratory Chemicals, $4^{\text {th }}$ Ed., W.L.F. Armarego and D.D. Perrin, Butterworth Heinemann, 1996. The bis-(2-methylallyl)cycloocta-1,5-diene-ruthenium(II) complex and ( $R$ )-2,2'-bis(diphenylphosphino)-1,1'-binaphthyl are from Acros. Organic layers were dried with $\mathrm{MgSO}_{4}$ or $\mathrm{Na}_{2} \mathrm{SO}_{4}$. Flash chromatography was performed on silica gel chromagel 60 ACC 35-70 $\mu \mathrm{m}$. Analytical TLC: aluminium-backed silica gel Merck $60 \mathrm{~F}_{254}$. Optical rotations were measured at $25^{\circ} \mathrm{C}$ on a Perkin-Elmer 241 polarimeter (1 dm cell). NMR spectra were recorded on a Brucker AC 200 or Avance 300 apparatus with chemical shift values $(\delta)$ in $\mathrm{ppm}$ downfield from tetramethylsilane. Microanalyses were performed by the Service de Microanalyse of ICSN, Gif-sur-Yvette, France. HRMS were performed by the Service de Spectrométrie de Masse of ICSN, Gif-sur-Yvette, France.

Methyl (2'S)-3-(N-tert-butoxycarbonyl-2'-pyrrolidinyl)-3-oxopropanoate (6). Carbonyldiimidazole (13.6 g, $84.0 \mathrm{mmol}, 1.2$ equiv.) was added to a solution of $N$-Boc-L-proline (5) (15.0 $\mathrm{g}, 69.8 \mathrm{mmol})$ in dry THF $(560 \mathrm{~mL})$. The reaction mixture was stirred at room temperature for 16 h. Magnesium salt of monomethylmalonate ( $10.9 \mathrm{~g}, 42.2 \mathrm{mmol}, 0.6$ equiv.) was added and the reaction mixture was stirred 5 days at room temperature. The solvents were evaporated and the residue was treated with an aqueous solution of $\mathrm{HCl}(2 \mathrm{~N})$ until $\mathrm{pH}$ 1. The aqueous layer was extracted with $\mathrm{Et}_{2} \mathrm{O}(4 \times 150 \mathrm{~mL})$. The combined organic layers were dried, filtered and the solvents were evaporated. Purification by silica gel chromatography $\left(\mathrm{Et}_{2} \mathrm{O} /\right.$ pentane: 1/1) gave 6 as white crystals $(16.6 \mathrm{~g}, 88 \%) ;[\alpha]_{\mathrm{D}}^{25}-77(c 1.3, \mathrm{DCM}) ;{ }^{1} \mathrm{H} \mathrm{NMR}\left(200 \mathrm{MHz}, \mathrm{CDCl}_{3}\right)$ : Ketoester: $\delta 1.42\left(\mathrm{~s}, 9 \mathrm{H}, \mathrm{OCMe}_{3}\right), 1.87-2.06\left(\mathrm{~m}, 4 \mathrm{H}, \mathrm{H}-3^{\prime}\right.$ and $\left.\mathrm{H}-4^{\prime}\right), 3.41-3.58\left(\mathrm{~m}, 4 \mathrm{H}, \mathrm{H}-2\right.$ and $\left.\mathrm{H}-5^{\prime}\right)$, 3.73 (s, $3 \mathrm{H}, \mathrm{OMe}$ ), 4.27 (m, $1 \mathrm{H}, \mathrm{H}-2^{\prime}$ ); Enol: $\delta 1.45$ (s, $9 \mathrm{H}, \mathrm{OCMe}_{3}$ ), 1.87-2.06 (m, $4 \mathrm{H}, \mathrm{H}-3^{\prime}$ and $\mathrm{H}^{-4}{ }^{\prime}$ ), 3.41-3.58 (m, $\left.2 \mathrm{H}, \mathrm{H}-5^{\prime}\right), 3.76$ (s, $\left.3 \mathrm{H}, \mathrm{OMe}\right), 4.27$ (m, $\left.1 \mathrm{H}, \mathrm{H}-2^{\prime}\right), 5.03$ (m, $\left.1 \mathrm{H}, \mathrm{H}-2\right)$; ${ }^{13} \mathrm{C}$ NMR (50 MHz, $\mathrm{CDCl}_{3}$ ), Ketoester + enol: $\delta$ 23.7, $24.4(\mathrm{C}-3$ ' or C-4'), 28.2, 28.3, 28.5 $\left(\mathrm{OCMe}_{3}\right), 29.4,29.7$ (C-3' or C-4'), 45.0, 46.1, 46.7 (C-2 and C-5'), 52.2, 52.3 (OMe), 65.0, 65.6 $\left(\mathrm{C}-2^{\prime}\right), 80.2,80.8\left(\mathrm{OCMe}_{3}\right), 153.8$ (CO), 167.4, 169.4 (C-1), 202.5 (C-3). Anal. Calcd for $\mathrm{C}_{13} \mathrm{H}_{21} \mathrm{NO}_{5}$ : C, 57.55; H, 7.80; N, 5.16. Found: C, 57.51; H, 7.54; N, 4.99.

Methyl (2'S)-3-(2'-pyrrolidinyl)-3-oxopropanoate, trifluoroacetate salt (7). TFA (1.5 mL) was added to $6(200 \mathrm{mg})$ and the overall was stirred during $15 \mathrm{~min}$. Concentration in vacuo led to the crude 7 (99\%), which was too unstable for analysis and was directly introduced in the next reaction; ${ }^{1} \mathrm{H}$ NMR $\left(200 \mathrm{MHz}, \mathrm{CDCl}_{3}\right): \delta 2.05-2.11\left(\mathrm{~m}, 3 \mathrm{H}, \mathrm{H}-3{ }^{\prime}\right.$ and $\left.\mathrm{H}-4{ }^{\prime}\right), 2.48\left(\mathrm{~m}, 1 \mathrm{H}, \mathrm{H}-3^{\prime}\right.$ or H-4'), 3.43-3.52 (m, 2 H, H-2 or H-5'), 3.66-3.80 (m, 5 H, H-2 or H-5' and OMe), 4.82 (m, $1 \mathrm{H}$, H-2'). 


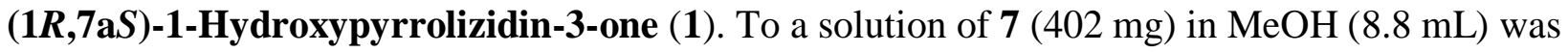
added slowly $\mathrm{NaBH}_{4}\left(56 \mathrm{mg}, 0.6\right.$ equiv.) at $-20{ }^{\circ} \mathrm{C}$. The temperature is let warm until $-10{ }^{\circ} \mathrm{C}$ for stirring $3 \mathrm{~h}$. Then concentration and purification by silica gel chromatography (EtOAc/ $\mathrm{MeOH}$ : 9/1 then 3.5/1.5) gave 1 as a major compound (229 mg, 57\%) and 2 (40 mg, 10\%). NMR spectral data are in concordance with those in the literature. ${ }^{12 \mathrm{~b}}$

Methyl (3S,2'S)-3-(N-tert-butoxycarbonyl-2'-pyrrolidinyl)-3-hydroxypropanoate (8). The $\left[(R)-\mathrm{BinapRu}_{\mathrm{B}} \mathrm{Br}_{2}\right.$ catalyst was prepared using the previously described procedure. ${ }^{29}$ Under argon,to bis-(2-methylallyl)-cycloocta-1,5-diene-ruthenium(II) complex (0.02 equiv.) and $(R)$ 2,2'-bis(diphenylphosphino)-1,1'-binaphthyl (0.02 equiv.) in degassed acetone $(1 \mathrm{~mL} / \mathrm{mmol}$ of catalyst) was added a methanolic solution of hydrogen bromide (0.15-0.18M, 0.04 equiv.). The reaction mixture was stirred one hour. The solvents were evaporated and the $\beta$-ketoester 6 (1 $\mathrm{mmol})$ in freshly distilled degassed $\mathrm{MeOH}(1.7 \mathrm{~mL})$ was cannulated to the catalyst. The reaction mixture was stirred at 100 bars and $50{ }^{\circ} \mathrm{C}$ during $48 \mathrm{~h}$. The solvents were evaporated and purification by silica gel chromatography (DCM/ $\mathrm{Et}_{2} \mathrm{O} / \mathrm{MeOH}: 100 / 30 / 4$ ) gave 8 (yield 97\%, d.e. $96 \%) ;[\alpha]_{\mathrm{D}}^{25}-63\left(c 0.1, \mathrm{CHCl}_{3}\right)$; $\mathrm{Lit}^{30}$ : $-62.69\left(c 4.17, \mathrm{CHCl}_{3}\right.$, value for 8); ${ }^{1} \mathrm{H} \mathrm{NMR}(200$ $\left.\mathrm{MHz}, \mathrm{CDCl}_{3}\right): \delta 1.47$ (s, $\left.9 \mathrm{H}, \mathrm{OCMe}_{3}\right), 1.58-1.93\left(\mathrm{~m}, 4 \mathrm{H}, \mathrm{H}-3^{\prime}\right.$ and $\left.\mathrm{H}-4{ }^{\prime}\right), 2.45-2.51(\mathrm{~m}, 2 \mathrm{H}, \mathrm{H}-$ 2), 3.33 (m, $\left.1 \mathrm{H}, \mathrm{H}-5^{\prime}\right), 3.43$ (m, $\left.1 \mathrm{H}, \mathrm{H}-5^{\prime}\right), 3.71$ (s, $\left.3 \mathrm{H}, \mathrm{OMe}\right), 3.92-4.04$ (m, $2 \mathrm{H}, \mathrm{H}-2^{\prime}$ and H3); ${ }^{13} \mathrm{C}$ NMR $\left(50 \mathrm{MHz}, \mathrm{CDCl}_{3}\right): \delta 24.0\left(\mathrm{C}-4^{\prime}\right), 28.4\left(\mathrm{C}-3^{\prime}\right.$ and $\mathrm{CMe}$ ) $), 40.4(\mathrm{C}-2), 47.3\left(\mathrm{C}-5^{\prime}\right)$, 51.8 (OMe), 61.8 (C-2'), 72.0 (C-3), $80.5\left(\mathrm{OCMe}_{3}\right), 172.4$ (C-1).

All mixtures of 8/9 were analysed by reverse phase HPLC: Kromasil C18-30*4, methanol / water $55: 45 ; 1 \mathrm{~mL} / \mathrm{min} ; \lambda=218 \mathrm{~nm}, \mathrm{P}=238 \mathrm{~kg} / \mathrm{cm}^{2}$; Samples $(10 \mathrm{mg})$ were prepared by passage through a cyanopropyl column (activated by $\mathrm{MeOH}(1 \mathrm{~mL})$ and $\mathrm{H}_{2} \mathrm{O}(1 \mathrm{~mL})$ ), washing with $\mathrm{H}_{2} \mathrm{O}(1 \mathrm{~mL})$, and elution with methanol/water 55:45 $(1 \mathrm{~mL})$; the resulting fraction was filtered over PVDF filter. 6: $\mathrm{rt}=10.24 \mathrm{~min} ; \mathbf{8}: \mathrm{rt}=12.72 \mathrm{~min} ; \mathbf{9}: \mathrm{rt}=13.95 \mathrm{~min}$.

$(\mathbf{S}, \mathbf{7 a S})$-1-Hydroxypyrrolizidin-3-one (2). The compound $8(155 \mathrm{mg}, 0.6 \mathrm{mmol})$ was stirred at room temperature in the presence of TFA $(3.2 \mathrm{~mL})$ during $10 \mathrm{~min}$. After evaporation of the solvent, the intermediate trifluoroacetate salt was introduced directly in the next step. A quick elution over silica gel chromatography $(\mathrm{MeOH})$ led to the pure intermediate $(153 \mathrm{mg}, 94 \%) ;{ }^{1} \mathrm{H}$ NMR (200 MHz, $\left.\mathrm{CDCl}_{3}\right): \delta 1.69$ (m, 1 H, H-4'), 2.08 (m, $3 \mathrm{H}, \mathrm{H}-3^{\prime}$ and H-4'), 2.57 (m, $2 \mathrm{H}, \mathrm{H}-$ 2), 3.34 (m, 2 H, H-5'), 3.67 (m, 4 H, H-2' and OMe), 4.17 (m, $1 \mathrm{H}, \mathrm{H}-3), 6.85$ (s, $1 \mathrm{H}, \mathrm{OH}), 8.68$ $(\mathrm{s}, 1 \mathrm{H}, \mathrm{NH}) ;{ }^{13} \mathrm{C} \mathrm{NMR}\left(50 \mathrm{MHz}, \mathrm{CDCl}_{3}\right): \delta 24.2\left(\mathrm{C}-3^{\prime}\right), 27.2\left(\mathrm{C}-4^{\prime}\right), 39.1$ (C-2), $45.1\left(\mathrm{C}-5^{\prime}\right)$, 52.0 (OMe), 64.3 (C-2'), 67.9 (C-3), 171.5 (C-1).

The impure salt was retaken in water $(1.5 \mathrm{~mL})$ and $\mathrm{K}_{2} \mathrm{CO}_{3}(287 \mathrm{mg})$ was added. After stirring $3 \mathrm{~h}$ at $90{ }^{\circ} \mathrm{C}$, the reaction mixture was concentrated and the crude was purified by silica gel chromatography (EtOAc/ MeOH: 85/15) to give 2 (161 mg, 94\% from 8). NMR spectral data are in accordance with those in the literature ${ }^{12 b}$.

Methyl (2'S)-3-oxo-(N-tert-butoxycarbonyl-5' -oxopyrrolidin-2'-yl)propanoate

(12). Magnesium chloride (920 mg, $9.8 \mathrm{mmol}, 1.6$ equiv.) was added to a solution of potassium monomethyl malonate $(2.60 \mathrm{~g}, 16.5 \mathrm{mmol}, 2.7$ equiv.) in dry THF (38 mL). The reaction mixture was cooled at $0{ }^{\circ} \mathrm{C}$, then triethylamine $(2.6 \mathrm{~mL}, 18.3 \mathrm{mmol}, 3.0$ equiv. $)$ was added and the whole 
was stirred at this temperature for $80 \mathrm{~min}$. In another flask, a solution of $\mathbf{1 1}^{22}(1.40 \mathrm{~g}, 6.1 \mathrm{mmol})$ in dry THF (8.4 mL) was added to carbonyldiimidazole (1.09 g, $6.7 \mathrm{mmol}, 1.1$ equiv.) in DMF $(6.7 \mathrm{~mL})$ and stirred for 40 minutes at room temperature. The second solution was then added to the salt at $0{ }^{\circ} \mathrm{C}$, and the reaction mixture was warmed to room temperature then stirred for four days. After filtration, the filtrate was diluted with water $(50 \mathrm{~mL})$ and extracted with EtOAc $(7 \times$ $30 \mathrm{~mL})$. The organic layers were washed with brine $(50 \mathrm{~mL})$, dried, then concentrated in vacuo to give a yellow oil. Purification by silica gel chromatography (EtOAc) gave $12(1.17 \mathrm{~g}, 67 \%)$; $[\alpha]_{\mathrm{D}}^{25}-12(c 0.4, \mathrm{MeOH}) ; \mathrm{mp} 91{ }^{\circ} \mathrm{C} ;{ }^{1} \mathrm{H} \mathrm{NMR}\left(200 \mathrm{MHz}, \mathrm{CDCl}_{3}\right): \delta 1.50(\mathrm{~s}, 9 \mathrm{H}, \mathrm{OCMe} 3), 1.95-$ 2.75 (m, 4 H, H-3' and H-4'), 3.55 (d, 1 H, J 15.8 Hz, H-2), 3.66 (d, 1 H, J 16.0 Hz, H-2), 3.77 (s, $3 \mathrm{H}, \mathrm{OMe}), 4.81$ (dd, $\left.1 \mathrm{H}, J 3.6 ; 9.3 \mathrm{~Hz}, \mathrm{H}-5{ }^{\prime}\right) ;{ }^{13} \mathrm{C} \mathrm{NMR}\left(75 \mathrm{MHz}, \mathrm{CDCl}_{3}\right): \delta 20.0\left(\mathrm{C}-4^{\prime}\right), 27.8$ (OCMe $), 31.0$ (C-3'), 46.1 (C-2), 52.6 (OMe), 63.8 (C-5'), $88.0\left(\mathrm{OCMe}_{3}\right), 149.5$ (CO), 166.8 (C1), 173.0 (C-2'), 199.6 (C-3). Anal. Calc. for $\mathrm{C}_{13} \mathrm{H}_{19} \mathrm{NO}_{6}$ : Calcd C 54.73, H 6.71, N 4.91; Found C 54.71, H 6.67, N 4.63.

Methyl (2'S,3S)-3-Hydroxy-3-(5'-oxopyrrolidin-2'-yl)propanoate (13). The protocol described for the preparation of $\mathbf{8}$ from $\mathbf{6}$, applied to $\mathbf{1 2}$ under hydrogen atmosphere at $55{ }^{\circ} \mathrm{C}$ during $40 \mathrm{~h}$ led to $\mathbf{1 3}$ after purification by silica gel chromatography (EtOAc/ MeOH: 95/5) (yield 97\%, d.e. 94\%); $[\alpha]_{\mathrm{D}}^{25}+9(c 0,9 ; \mathrm{MeOH}) ; \mathrm{mp} 94{ }^{\circ} \mathrm{C} ;{ }^{1} \mathrm{H} \mathrm{NMR}\left(300 \mathrm{MHz}, \mathrm{CDCl}_{3}\right): \delta 1.77$ (m, $\left.1 \mathrm{H}, \mathrm{H}-4^{\prime}\right), 2.18$ (m, $\left.1 \mathrm{H}, \mathrm{H}-4^{\prime}\right), 2.35-2.58$ (m, $4 \mathrm{H}, \mathrm{H}-2$ and $\mathrm{H}-3$ '), 2.75 (broad s, $1 \mathrm{H}, \mathrm{OH}$ ), 3.62 (dd, 1 H, J 7.1; $14.1 \mathrm{~Hz}, \mathrm{H}-5$ '), 3.73 (s, 3 H, OMe), 3.86 (td, $1 \mathrm{H}, J$ 3.2; 8.1 Hz, H-3), 6.76 (broad s, $1 \mathrm{H}, \mathrm{NH}) ;{ }^{13} \mathrm{C}$ NMR $\left(75 \mathrm{MHz}, \mathrm{CDCl}_{3}\right): \delta 23.4\left(\mathrm{C}-4^{\prime}\right), 30.2\left(\mathrm{C}-3^{\prime}\right), 37.6(\mathrm{C}-2), 52.1$ (OMe), $58.4\left(\mathrm{C}-5^{\prime}\right), 71.7$ (C-3), $172.4(\mathrm{C}-1), 178.3\left(\mathrm{C}-2^{\prime}\right)$. Anal. Calc. for $\mathrm{C}_{8} \mathrm{H}_{13} \mathrm{NO}_{4}$ : Calcd C 51.33, H 7.00, N 7.48; Found C 51.48, H 7.09, N 7.51.

Methyl (2'S,3R)-3-Hydroxy-3-(5'-oxopyrrolidin-2'-yl)propanoate (14). The protocol described for the preparation of $\mathbf{8}$ from $\mathbf{6}$, applied to $\mathbf{1 2}$ in the presence of $\left[(S)-\mathrm{BinapRu}_{\mathrm{Br}} \mathrm{Br}_{2}\right.$ under hydrogen atmosphere at $55{ }^{\circ} \mathrm{C}$ during $40 \mathrm{~h}$ led to $\mathbf{1 4}$ after purification by silica gel chromatography (EtOAc/ MeOH: 95/5) (yield 89\%, d.e. 99\%); $[\alpha]_{\mathrm{D}}^{25}+5(c 1.0 ; \mathrm{MeOH}) ; \mathrm{mp} 129$ ${ }^{\circ} \mathrm{C} ;{ }^{1} \mathrm{H}$ NMR (200 MHz, $\left.\mathrm{CDCl}_{3}\right): \delta$ 1.91-2.52 (m, $6 \mathrm{H}, \mathrm{H}-2, \mathrm{H}-3{ }^{\prime}$ and $\mathrm{H}-4$ '), 3.74-3.80 (m, $4 \mathrm{H}$, $\mathrm{H}-5^{\prime}$ and $\left.\mathrm{OMe}\right), 4.05(\mathrm{~m}, 1 \mathrm{H}, \mathrm{H}-3), 6.20$ (broad s, $\left.1 \mathrm{H}, \mathrm{NH}\right) ;{ }^{13} \mathrm{C} \mathrm{NMR}\left(75 \mathrm{MHz}, \mathrm{CDCl}_{3}\right)$ : $\delta 21.2\left(\mathrm{C}-4^{\prime}\right), 29.8\left(\mathrm{C}-3^{\prime}\right), 36.9$ (C-2), 52.0 (OMe), 58.1 (C-5'), 69.5 (C-3), 172.7 (C-1), 179.2 (C$2^{\prime}$ ). Anal. Calc. for $\mathrm{C}_{8} \mathrm{H}_{13} \mathrm{NO}_{4}$ : Calcd C 51.33, H 7.00, N 7.48; Found C 51.49, H 7.12, N 7.39.

Methyl (2'S,3S)-3-(tert-butyldimethylsilyloxy)-3-(5'-oxopyrrolidin-2'-yl)propanoate (15). Under argon, a solution of imidazole (771 mg, $11.3 \mathrm{mmol}, 2.6$ eq.) in dry DMF (9.7 mL) was cannulated to a flask containing $13(816 \mathrm{mg}, 4.4 \mathrm{mmol})$. tert-butyldimethylsilyl chloride (1.18 g, $7.8 \mathrm{mmol}, 1.8$ eq.) was added and the reaction mixture was stirred at room temperature during 24 h. Water was then added $(10 \mathrm{~mL})$, and the compound was extracted with $\mathrm{Et}_{2} \mathrm{O}(4 \times 10 \mathrm{~mL})$. The organic layers were dried and concentrated under vacuum to give a crude product which after purification by silica gel chromatography (EtOAc) gave $15(988 \mathrm{mg}, 75 \%) ;[\alpha]_{\mathrm{D}}^{25}-16(c 0.5$; $\mathrm{MeOH}) ;{ }^{1} \mathrm{H}$ NMR (300 MHz, $\mathrm{CDCl}_{3}$ ): $\delta 0.08$ (s, $3 \mathrm{H}, \mathrm{SiMe}$ ), 0.12 (s, $3 \mathrm{H}, \mathrm{SiMe}$ ), 0.88 (s, $9 \mathrm{H}$, $\mathrm{SiCMe}_{3}$ ), 1.80 (m, $\left.1 \mathrm{H}, \mathrm{H}-4^{\prime}\right), 2.16-2.55$ (m, 5 H, H-2, H-3' and H-4'), 3.70-3.76 (m, 4 H, H-5' and $\mathrm{OMe}), 3.97(\mathrm{dd}, 1 \mathrm{H}, J$ 5.7; $12.4 \mathrm{~Hz}, \mathrm{H}-3), 5,66$ (broad s, $1 \mathrm{H}, \mathrm{NH}) ;{ }^{13} \mathrm{C} \mathrm{NMR}(75 \mathrm{MHz}$, 
$\left.\mathrm{CDCl}_{3}\right): \delta$-5.1 (SiMe $)$, -4.6 (SiMe $\left.e_{2}\right), 17.9\left(\mathrm{SiCMe}_{3}\right), 22.9\left(\mathrm{C}-4{ }^{\prime}\right), 25.7\left(\mathrm{SiCMe}_{3}\right), 29.9\left(\mathrm{C}-3^{\prime}\right)$, 38.9 (C-2), 51.8 (OMe), 58.2 (C-5'), 72.6 (C-3), 171.2 (C-1), 177.6 (C-2'). Anal. Calc. for $\mathrm{C}_{14} \mathrm{H}_{27} \mathrm{NO}_{4} \mathrm{Si}$ : Calcd C 55.78, H 9.03, N 4.65; Found C 55.49, H 9.03, N 4.75.

(2'S,3S)-3-(tert-Butyldimethylsilyloxy)-3-(5'-oxopyrrolidin-2'-yl)propanol (16). Sodium borohydride (1.83 g, $48.2 \mathrm{mmol}, 15.0$ eq.) was added slowly to a solution of $\mathbf{1 5}$ (967 $\mathrm{mg}, 3.2$ $\mathrm{mmol})$ in dry $\mathrm{MeOH}(10 \mathrm{~mL})$ at $0{ }^{\circ} \mathrm{C}$ under argon. After $2 \mathrm{~h} 30 \mathrm{~m}$ of stirring at room temperature, brine $(2 \mathrm{~mL})$ then an aqueous solution of $\mathrm{HCl} 1 \mathrm{~N}$ was added until neutral $\mathrm{pH}$. The aqueous layer was extracted with DCM $(5 \times 10 \mathrm{~mL})$, and the organic layers were dried and concentrated in vacuo. The crude was purified by silica gel chromatography (DCM/ MeOH: 9/1) to give 16 (824 mg, 94\%); $[\alpha]_{\mathrm{D}}^{25}+10$ (c1.0; DCM); mp $81{ }^{\circ} \mathrm{C} ;{ }^{1} \mathrm{H}$ NMR $\left(300 \mathrm{MHz}, \mathrm{CDCl}_{3}\right): \delta 0.10(\mathrm{~s}, 3 \mathrm{H}$, $\mathrm{SiMe}$ ), 0.11 (s, $3 \mathrm{H}, \mathrm{SiMe}_{2}$ ), 0.91 (s, 9 H, SiCMe $)$ ), 1.65-1.87 (m, 3 H, H-3' and H-2), 2.12-2.44 (m, 4 H, H-4', H-3' and OH), 3.70-3.85 (m, 4 H, H-2', H-3 and H-1); 6,19 (broad s, $1 \mathrm{H}, \mathrm{NH}$ ); ${ }^{13} \mathrm{C}$ NMR (75 MHz, $\left.\mathrm{CDCl}_{3}\right): \delta$-4.6 ( $\left.\mathrm{SiMe}_{2}\right),-4.4\left(\mathrm{SiMe}_{2}\right), 17.9\left(\mathrm{SiCMe}_{3}\right), 23.3(\mathrm{C}-3$ '), 25.8 (SiCMe 3 ), 30.2 (C-4'), 35.4 (C-2), 58.2 (C-2'), 58.3 (C-1), 73.8 (C-3), 178.0 (C-5'). Anal. Calc. for $\mathrm{C}_{13} \mathrm{H}_{27} \mathrm{NO}_{3} \mathrm{Si}$ : Calcd C 57.10, H 9.95, N 5.12; Found C 56.51, H 9.89, N 5.03.

(7S,7aS)-7-(tert-Butyldimethylsilyloxy)pyrrolizidin-3-one (3).To a solution of $\mathbf{1 6}$ (135 mg, 0.5 $\mathrm{mmol})$ in dry DCM (3 mL) under argon was added methanesulfonyl chloride (132 $\mu \mathrm{L}, 1.7 \mathrm{mmol}$, 3.5 equiv.) then freshly distilled triethylamine $(180 \mu \mathrm{L}, 1.3 \mathrm{mmol}, 2.6$ equiv. $)$. After stirring 12 hours, EtOAc $(10 \mathrm{~mL})$ was added and the organic layer was washed successively with distilled water $(5 \mathrm{~mL})$, a saturated aqueous solution of $\mathrm{NaHCO}_{3}(5 \mathrm{~mL})$, then brine $(5 \mathrm{~mL})$. After drying, filtration and concentration under vacuo, the orange oil was retaken into anhydrous THF $(9 \mathrm{~mL})$ under argon and cooled at $0{ }^{\circ} \mathrm{C}$. Sodium hydride (suspension in oil 60\%, $40 \mathrm{mg}, 1.0 \mathrm{mmol}, 2.0$ equiv.) was added to the reaction mixture and the overall was stirred at room temperature during $24 \mathrm{~h}$. After hydrolysis with aqueous saturated $\mathrm{NH}_{4} \mathrm{Cl}$ until neutral $\mathrm{pH}$, the aqueous layer was extracted with EtOAc $(3 \times 5 \mathrm{~mL})$. The organic layers were dried, concentrated for give a crude which was purified by silica gel chromatography (EtOAc) to led to $3(84 \%) ;[\alpha]_{\mathrm{D}}^{25}+33(c 0.5$, $\left.\mathrm{CHCl}_{3}\right)\left(\right.$ Lit. $\left.^{18}[\alpha]_{\mathrm{D}}^{25}+33\left(c 1.0, \mathrm{CHCl}_{3}\right)\right)$.

Methyl (2'S,3R)-3-(tert-Butyldimethylsilyloxy)-3-(5'-oxopyrrolidin-2'-yl)propanoate (17). The protocol described for the preparation of 15 from 13, applied to 14 led to $17(88 \%) ;[\alpha]_{\mathrm{D}}^{25}+4$ $(c 0,6 ; \mathrm{MeOH}) ;{ }^{1} \mathrm{H} \mathrm{NMR}\left(200 \mathrm{MHz}, \mathrm{CDCl}_{3}\right): \delta 0.05\left(\mathrm{~s}, 3 \mathrm{H}, \mathrm{Si} M e_{2}\right), 0.08$ (s, $\left.3 \mathrm{H}, \mathrm{SiMe}\right), 0.86$ (s, $9 \mathrm{H}, \mathrm{SiCMe}_{3}$ ), 1.83-2.56 (m, $6 \mathrm{H}, \mathrm{H}-2, \mathrm{H}-3^{\prime}$ and $\left.\mathrm{H}-4^{\prime}\right), 3.68-3.78$ (m, $4 \mathrm{H}, \mathrm{H}-5^{\prime}$ and $\mathrm{OMe}$ ), 4.14 $(\mathrm{m}, 1 \mathrm{H}, \mathrm{H}-3), 6.11$ (broad s, $1 \mathrm{H}, \mathrm{NH}) ;{ }^{13} \mathrm{C} \mathrm{NMR}\left(75 \mathrm{MHz}, \mathrm{CDCl}_{3}\right): \delta-5.1\left(\mathrm{Si}_{2}\right)$, 4.8 ( $\left.\mathrm{SiMe} e_{2}\right), 17.7\left(\mathrm{SiCMe}_{3}\right), 20.7\left(\mathrm{C}-4{ }^{\prime}\right), 25.6\left(\mathrm{SiCMe}_{3}\right), 29.9\left(\mathrm{C}-3^{\prime}\right), 38.7$ (C-2), $51.8(\mathrm{OMe})$, 58.3 (C-5'), 70.9 (C-3), 171.3 (C-1), 178.7 (C-2'). Anal. Calc. for $\mathrm{C}_{14} \mathrm{H}_{27} \mathrm{NO}_{4} \mathrm{Si}$ : Calcd C 55.78, H 9.03, N 4.65; Found C 55.74, H 9.17, N 4.69.

(2'S,3R)-3-(tert-Butyldimethylsilyloxy)-3-(5'-oxopyrrolidin-2'-yl)propanol (18). The protocol described for the preparation of $\mathbf{1 6}$ from 15, applied to 17 led to $\mathbf{1 8}(77 \%)$ with recovery of 17 $(15 \%) ;[\alpha]_{\mathrm{D}}^{25}+17(c 0,5 ; \mathrm{DCM}) ;{ }^{1} \mathrm{H} \mathrm{NMR}\left(200 \mathrm{MHz}, \mathrm{CDCl}_{3}\right): \delta 0.07$ (s, $3 \mathrm{H}, \mathrm{SiMe}$ ), $0.08(\mathrm{~s}, 3 \mathrm{H}$, $\mathrm{Si} \mathrm{e}_{2}$ ), 0.88 (s, $9 \mathrm{H}, \mathrm{SiCMe}_{3}$ ), 1.72-2.51 (m, $7 \mathrm{H}, \mathrm{H}-4$ ', H-3', H-2 and $\mathrm{OH}$ ), 3.64-3.82 (m, 4 H, 
H-2', H-3 and H-1), 6.95 (broad s, $1 \mathrm{H}, \mathrm{NH}) ;{ }^{13} \mathrm{C}$ NMR (75 MHz, $\left.\mathrm{CDCl}_{3}\right): \delta-4.6\left(\mathrm{Si}_{2}\right), 17.9$ ( $\mathrm{SiCMe}_{3}$ ), 22.2 (C-3'), 25.7 (SiCMe 3 ), 30.1 (C-4'), 36.1 (C-2), 58.3 (C-2'), 58.6 (C-1), 72.4 (C3), 179.1 (C-5'). Anal. Calc. for $\mathrm{C}_{13} \mathrm{H}_{27} \mathrm{NO}_{3} \mathrm{Si}$ : Calcd C 57.10, H 9.95, N 5.12; Found C 56.58, H 10.17, N 5.11.

(7R,7aS)-7-(tert-Butyldimethylsilyloxy)pyrrolizidin-3-one (4). The protocol described for the preparation of 3 from 16, applied to 18 led to $\mathbf{4}(85 \%)$; $[\alpha]_{\mathrm{D}}^{25}-37\left(c 0.4, \mathrm{CHCl}_{3}\right)\left(\mathrm{Lit}^{4}{ }^{4}[\alpha]_{\mathrm{D}}^{25}+38\right.$ $\left(c 0.9, \mathrm{CHCl}_{3}\right)$ for ent-4); ${ }^{1} \mathrm{H} \mathrm{NMR}\left(300 \mathrm{MHz}, \mathrm{CDCl}_{3}\right): \delta 0.04(\mathrm{~s}, 6 \mathrm{H}, \mathrm{SiMe} 2), 0.87$ (s, $9 \mathrm{H}$, $\mathrm{SiCMe}_{3}$ ), 1.74 (m, $1 \mathrm{H}, \mathrm{H}-1$ ), 1.93 (m, $1 \mathrm{H}, \mathrm{H}-6$ ), 2.14-2.42 (m, $3 \mathrm{H}, \mathrm{H}-1, \mathrm{H}-2$ and H-6), 2.66 (m, $1 \mathrm{H}, \mathrm{H}-2), 3.17$ (m, 1 H, H-5), 3.58 (m, 1 H, H-5), 3.69 (dd, 1 H, J 6.9; 13.9 Hz, H-7a), 3.81 (dd, $1 \mathrm{H}, J$ 6.9; $13.7 \mathrm{~Hz}, \mathrm{H}-7) ;{ }^{13} \mathrm{C} \mathrm{NMR}\left(75 \mathrm{MHz}, \mathrm{CDCl}_{3}\right): \delta-4.8\left(\mathrm{SiMe}_{2}\right),-4.7(\mathrm{SiMe}), 17.9$ ( $\mathrm{SiCMe}_{3}$ ), 25.1 (C-1), 25.6 (SiCMe $), 34.3$ (C-2), 35.7 (C-6), 39.8 (C-5), 67.4 (C-7a), 76.6 (C-7), 178.1 (C-3); ESI-HMRS: $m / z$ calcd for $\mathrm{C}_{13} \mathrm{H}_{25} \mathrm{NO}_{2} \mathrm{NaSi}[\mathrm{M}+\mathrm{Na}]^{+}:$278.1552; found: 278.1556.

Methyl (2S,4R)-1-tert-butoxycarbonyl-4-[ $N, N^{\prime}$-di(benzyloxycarbonyl)hydrazino]-5oxopyrrolidine-2-carboxylate (20). A solution of LiHMDS (1M in THF, $1.4 \mathrm{~mL}, 1.1$ equiv.) in THF (8.5 mL) was added slowly to a solution of $\mathbf{1 9}^{26}(320 \mathrm{mg}, 1.3 \mathrm{mmol})$ in THF (6.8 mL) at $78{ }^{\circ} \mathrm{C}$ under argon. After stirring 1 hour, a solution of DBAD (790 mg, 2.6 mmol, 2.0 equiv.) in THF (2.6 mL) was added. The overall was stirred 4 hours at this temperature, then was quenched with saturated aqueous $\mathrm{NH}_{4} \mathrm{Cl}(20 \mathrm{~mL})$. The aqueous layer was extracted with $\mathrm{DCM}(4 \times 10$ $\mathrm{mL}$ ), dried and concentrated to give $1.2 \mathrm{~g}$ of yellow oil. Purification by silica gel chromatography ( $\mathrm{Et}_{2} \mathrm{O} /$ pentane: 1/1) gave 20 (468 mg, $66 \%$, d.e.>95\%), which was too unstable to give correct elemental analysis; ${ }^{1} \mathrm{H}$ NMR (200 MHz, $\left.\mathrm{CDCl}_{3}\right): \delta 1.49\left(\mathrm{~s}, 9 \mathrm{H}, \mathrm{OCMe}_{3}\right), 1.68$ (m, 1 H, H-3), 2.46 (m, 1 H, H-3), 3.79 (s, 3 H, OMe), 4.58 (m, 1 H, H-4), 5.11-5.18 (m, 5 H, H2 and $\left.\mathrm{CH}_{2} \mathrm{Ph}\right), 6.84(\mathrm{~s}, 1 \mathrm{H}, \mathrm{NH}), 7.31(\mathrm{~m}, 10 \mathrm{H}, \mathrm{Ar}) ;{ }^{13} \mathrm{C} \mathrm{NMR}\left(75 \mathrm{MHz}, \mathrm{CDCl}_{3}\right): \delta 25.5(\mathrm{C}-3)$ $27.9\left(\mathrm{OCMe}_{3}\right), 31.0(\mathrm{C}-2), 52.9(\mathrm{OMe}), 55.7(\mathrm{C}-4), 68.1\left(\mathrm{CH}_{2} \mathrm{Ph}\right), 68.8\left(\mathrm{CH}_{2} \mathrm{Ph}\right), 84.4\left(\mathrm{OCMe}_{3}\right)$, 127.8-135.3 (Ar), 149.0 (CO), 155.3 (CO), 171.2 (CO).

Methyl (2S,4R)-4-Amino-5-oxopyrrolidine-2-carboxylate, trifluoroacetate salt (21). To the derivative 20 (1.7 g, $3.1 \mathrm{mmol})$ dissolved in $\mathrm{MeOH}(40 \mathrm{~mL})$, was added $\mathrm{Pd} / \mathrm{C}(88 \mathrm{mg})$. The overall was stirred vigorously under an atmospheric pressure of dihydrogen for 2 hours. Then Raney nickel was added, and the overall was stirred until the disappearance of the intermediate hydrazine (12 hours). The reaction mixture was passed through celite and washed with $\mathrm{MeOH}$ for give crude $(518 \mathrm{mg})$ as yellow-green crystals. Purification under flash chromatography (EtOAc) gave two products, corresponding to the $1 N$-Boc and the $3 N$-Boc derivatives of 20 $(64 \%)$. Each one was treated as follows, to give the same final derivative 21: they were retaken into TFA (0.85 $\mathrm{mL}$ for $80 \mathrm{mg}$ of substrate), and after stirring $10 \mathrm{~min}$ the mixture was concentrated to give yellow and very hygroscopic crystals of $21\left(86 \% ; 55 \%\right.$ from 20); $[\alpha]_{D}^{25}-40$ $(c 1.6, \mathrm{MeOH}) ;{ }^{1} \mathrm{H}$ NMR (200 MHz, CD $\left.3 \mathrm{OD}\right): \delta 2.45$ (m, $\left.1 \mathrm{H}, \mathrm{H}-3\right), 2.73(\mathrm{~m}, 1 \mathrm{H}, \mathrm{H}-3), 3.77$ (s, $3 \mathrm{H}, \mathrm{OMe}$ ), 4.09 (dd, $1 \mathrm{H}, J$ 10.2; $8.7 \mathrm{~Hz}, \mathrm{H}-4), 4.36$ (dd, $1 \mathrm{H}, J$ 9.3; 1.1, H-2), 5.34 (s, $3 \mathrm{H}, \mathrm{NH}$ );

${ }^{13} \mathrm{C} \mathrm{NMR}$ (75 MHz, CD $\left.{ }_{3} \mathrm{OD}\right)$ (major rotamer): $\delta 30.8$ (C-3), $50.2(\mathrm{C}-2), 53.3(\mathrm{OMe}), 54.1(\mathrm{C}-4)$, $117.7\left(\mathrm{CF}_{3} \mathrm{CO}_{2}^{-}\right), 160.2\left(\mathrm{CF}_{3} \mathrm{CO}_{2}^{-}\right), 173.4(\mathrm{CO}), 173.6(\mathrm{CO})$. Anal. Calc. for $\mathrm{C}_{8} \mathrm{H}_{11} \mathrm{~F}_{3} \mathrm{~N}_{2} \mathrm{O}_{5}$ : Calcd C 35.30, H 4.07, N 10.29; Found C 35.52, H 4.29, N 9.26. 
Benzyl (2S,4R)-1-tert-butoxycarbonyl-4-hydroxy-5-oxopyrrolidine-2-carboxylate (23). To a solution of $22^{22}(5.1 \mathrm{~g}, 16.0 \mathrm{mmol})$ in anhydrous THF $(87 \mathrm{~mL})$ under argon at $-78{ }^{\circ} \mathrm{C}$, was added a solution of LiHMDS (1 $M$ in THF, $16.0 \mathrm{~mL}, 16.0 \mathrm{mmol}, 1.0$ equiv.) in anhydrous THF (92 $\mathrm{mL}$ ). After stirring 1 hour, a solution of $N$-p-toluenesulfonyl-3-phenyloxaziridine (TPO) (6.6 g, $24.0 \mathrm{mmol}, 1.5$ equiv.) in anhydrous THF $(87 \mathrm{~mL})$ was added. After an additionnal $45 \mathrm{~min}$, the reaction mixture was quenched with a solution of CSA ( $0.5 M$ in THF, 5.0 equiv.) and let warm to room temperature. Then water $(500 \mathrm{~mL})$ was added, and the crude was extracted with DCM (5 $\times 250 \mathrm{~mL}$ ). The organic layers were successively washed with a solution of saturated sodium thiosulfate $(500 \mathrm{~mL})$, then brine $(500 \mathrm{~mL})$, and then dried and concentrated togive a crude material which was purified by silica gel chromatography $\left(\mathrm{Et}_{2} \mathrm{O}\right)$ to give $23(55 \%) ;[\alpha]_{\mathrm{D}}^{25}+15$ (c0.4, DCM); mp $98{ }^{\circ} \mathrm{C} ;{ }^{1} \mathrm{H}$ NMR $\left(300 \mathrm{MHz} \mathrm{CDCl}_{3}\right): \delta 1.44$ (s, $\left.9 \mathrm{H}, \mathrm{OCMe}\right), 2.22(\mathrm{~m}, 1 \mathrm{H}, \mathrm{H}-$ 3), 2.51 (m, $1 \mathrm{H}, \mathrm{H}-3$ ), 4.43 (dd, $1 \mathrm{H}, J 12.5-12.8$; 16.1-16.5 Hz, H-4), 4.66 (dd, $1 \mathrm{H}, J$ 1.3-1.6; 14.5-14.8 Hz, H-2), 5.22 (s, $2 \mathrm{H}, \mathrm{CH}_{2} \mathrm{Ph}$ ), 7.37 (s, $\left.5 \mathrm{H}, \mathrm{Ar}\right) ;{ }^{13} \mathrm{C} \mathrm{NMR}\left(75 \mathrm{MHz}, \mathrm{CDCl}_{3}\right): \delta 27.6$ $\left(\mathrm{OCMe}_{3}\right), 30.6$ (C-3), $55.5(\mathrm{C}-2), 67.5\left(\mathrm{CH}_{2} \mathrm{Ph}\right), 68.4(\mathrm{C}-4), 84.2\left(\mathrm{OCMe}_{3}\right), 128.5,128.6,134.8$ (Ar), 148.7 (CO), 170.5, 174.8 (C-5 and $\mathrm{CO}_{2} \mathrm{Bn}$ ); Anal. Calcd for $\mathrm{C}_{17} \mathrm{H}_{21} \mathrm{NO}_{6}$ : C, 60.89; $\mathrm{H}, 6.31$; N, 4.18. Found: C, 60.83; H, 6.43; N, 4.18 .

Benzyl (2S,4R)-1-tert-butoxycarbonyl-4-tert-butyldimethylsilyloxy-5-oxopyrrolidine-2carboxylate (24). To a solution of $23(2.9 \mathrm{~g}, 8.7 \mathrm{mmol})$ in DMF (85 mL) under argon, was added imidazole (3.5 g, $51.9 \mathrm{mmol}, 6.0$ equiv.) then tert-butyldimethylsilyl chloride (4.2 $\mathrm{g}, 27.7$ mmol, 3.2 equiv.). The overall was warmed at $70{ }^{\circ} \mathrm{C}$ during $3.5 \mathrm{~h}$, then water $(85 \mathrm{~mL})$ was added at room temperature. The aqueous layer was extracted with $\mathrm{Et}_{2} \mathrm{O}(4 \times 90 \mathrm{~mL})$, and the organic layers were dried and concentrated. A purification by silica gel chromatography $\left(\mathrm{Et}_{2} \mathrm{O} /\right.$ pentane: 1/2) gave 24 (3.6 g, 92\%); $[\alpha]_{\mathrm{D}}^{25}+13(c 1.5, \mathrm{DCM}) ;{ }^{1} \mathrm{H} \mathrm{NMR}\left(300 \mathrm{MHz}, \mathrm{CDCl}_{3}\right): \delta 0.10(\mathrm{~s}, 3 \mathrm{H}$, $\mathrm{SiMe}$ ), 0.16 (s, $3 \mathrm{H}, \mathrm{SiMe}$ ), 0.88 (s, $9 \mathrm{H}, \mathrm{SiCMe}_{3}$ ), 1.45 (s, $9 \mathrm{H}, \mathrm{OCMe}$ ), 2.19 (dt, $1 \mathrm{H}, J$ 9.9; $13.1 \mathrm{~Hz}, \mathrm{H}-3$ ), 2.34 (ddd, $1 \mathrm{H}, J 1.5 ; 8.3 ; 13.1 \mathrm{~Hz}, \mathrm{H}-3$ ), 4.38 (dd, $1 \mathrm{H}, J$ 8.3; $10.2 \mathrm{~Hz}, \mathrm{H}-4), 4.61$ $(\mathrm{dd}, 1 \mathrm{H}, J$ 1.5; $9.6 \mathrm{~Hz}, \mathrm{H}-2), 5.22\left(\mathrm{~s}, 2 \mathrm{H}, \mathrm{CH}_{2} \mathrm{Ph}\right), 7.37$ (s, $\left.5 \mathrm{H}, \mathrm{Ar}\right) ;{ }^{13} \mathrm{C} \mathrm{NMR}(75 \mathrm{MHz}$, $\left.\mathrm{CDCl}_{3}\right): \delta$-5.4 ( $\left.\mathrm{SiMe}_{2}\right),-4.5(\mathrm{SiMe}), 18.2\left(\mathrm{SiCMe}_{3}\right), 25.6\left(\mathrm{SiCMe}_{3}\right), 28.0\left(\mathrm{OCMe}_{3}\right), 31.9(\mathrm{C}-3)$, $55.1(\mathrm{C}-2), 67.4\left(\mathrm{CH}_{2} \mathrm{Ph}\right), 69.6(\mathrm{C}-4), 83.9\left(\mathrm{OCMe}_{3}\right), 128.5,128.7,135.0$ (Ar), $149.4(\mathrm{CO})$, 171.0, 172.0 (C-5 and $\mathrm{CO}_{2} \mathrm{Bn}$ ); Anal. Calcd for $\mathrm{C}_{23} \mathrm{H}_{35} \mathrm{NO}_{6} \mathrm{Si}$ : C, 61.44; H, 7.85; N, 3.12. Found: C, 61.41; H, 7.99; N, 3.11.

Methyl (2'R,4'S)-3-[N-tert-butoxycarbonyl-4' -(tert-butyldimethylsilyloxy)-5' -oxopyrrolidin2'-yl]-3-oxopropanoate (25). The hydrogenolysis of a solution of 24 (3.6 g, $8.0 \mathrm{mmol})$ in EtOAc $(5 \mathrm{~mL})$ in the presence of $\mathrm{Pd} / \mathrm{C}(10 \%)$ at 10 bars during $1 \mathrm{~h}$ led to the intermediate carboxylic acid after filtration through celite and concentration $(2.8 \mathrm{~g}, 98 \%) ;{ }^{1} \mathrm{H} \mathrm{NMR}\left(300 \mathrm{MHz}, \mathrm{CDCl}_{3}\right): \delta$ 0.14 (s, 3 H, SiMe $), 0.18$ (s, 3 H, SiMe $), 0.91$ (s, 9 H, SiCMe $), 1.52$ (s, 9 H, OCMe $), 2.25$ (m, $1 \mathrm{H}, \mathrm{H}-4), 2.48$ (m, $1 \mathrm{H}, \mathrm{H}-4), 3.85$ (broad s, $1 \mathrm{H}, \mathrm{COOH}$ ), 4.45 (dd, $1 \mathrm{H}, J=8.3 ; 10.0 \mathrm{~Hz}, \mathrm{H}-3$ ), $4.63(\mathrm{~d}, 1 \mathrm{H}, J=9.6 \mathrm{~Hz}, \mathrm{H}-5) ;{ }^{13} \mathrm{C} \mathrm{NMR}\left(75 \mathrm{MHz}, \mathrm{CDCl}_{3}\right): \delta-5.3\left(\mathrm{SiMe}_{2}\right),-4.5\left(\mathrm{SiMe}_{2}\right), 18.2$ $\left(\mathrm{SiCMe}_{3}\right), 25.6$ (SiCMe$), 28.0\left(\mathrm{OCMe}_{3}\right), 31.7$ (C-4), 54.8 (C-5), 69.7 (C-3), $84.3\left(\mathrm{OCMe}_{3}\right)$, $149.7(\mathrm{CO}), 171.9(\mathrm{C}-2), 176.1\left(\mathrm{CO}_{2} \mathrm{H}\right)$. 
Under argon, carbonyldiimidazole (1.5 g, $9.3 \mathrm{mmol}, 1.2$ equiv.) was added to a solution of the acid $(2.8 \mathrm{mg}, 7.8 \mathrm{mmol})$ in dry THF $(64 \mathrm{~mL})$ and the mixture was stirred $16 \mathrm{~h}$ at room temperature. In another flask, to a solution of potassium monomethyl malonate (4.3 g, 27.3 mmol, 3.5 equiv.) in dry $\mathrm{THF}(33 \mathrm{~mL})$ at $5{ }^{\circ} \mathrm{C}$ was added triethylamine $(5.0 \mathrm{~mL}, 35.9 \mathrm{mmol}, 4.6$ equiv.) and magnesium chloride ( $3.1 \mathrm{~g}, 33.5 \mathrm{mmol}, 4.3$ equiv.). The overall was stirred at room temperature during $3 \mathrm{~h}$ then cooled again at $0{ }^{\circ} \mathrm{C}$ before the addition of the acylimidazolide previously prepared. The reaction mixture was let warmed to room temperature then stirred during 4 days. THF was evaporated and the residue was dissolved in aqueous $1 M \mathrm{HCl}$ until pH 5-6. After extraction with DCM $(5 \times 300 \mathrm{~mL})$, the organic layers were dried and concentrated. A purification by silica gel chromatography ( $\mathrm{Et}_{2} \mathrm{O} /$ pentane: 1/1) gave $25(2.5 \mathrm{~g}, 76 \%)$; $[\alpha]_{\mathrm{D}}^{25}+42$ (c0.5, DCM); mp $65{ }^{\circ} \mathrm{C}$; ${ }^{1} \mathrm{H}$ NMR $\left(200 \mathrm{MHz}, \mathrm{CDCl}_{3}\right): \delta 0.13$ (s, $\left.3 \mathrm{H}, \mathrm{SiMe} 2\right), 0.18$ (s, $3 \mathrm{H}$, $\mathrm{SiMe}_{2}$ ), 0.90 (s, $9 \mathrm{H}, \mathrm{SiCMe}_{3}$ ), 1.51 (s, $9 \mathrm{H}, \mathrm{OCMe}_{3}$ ), 2.15 (dt, $1 \mathrm{H}, J$ 9.8; $13.3 \mathrm{~Hz}, \mathrm{H}-4$ '), 2.38 (ddd, 1 H, $J$ 1.9; 8.3; 13.3 Hz, H-4'), 3.57 (d, 1 H, J $16.0 \mathrm{~Hz}, \mathrm{H}-2$ ), 3.71 (d, $1 \mathrm{H}, J 16.0 \mathrm{~Hz}, \mathrm{H}-2$ ), 3.78 (s, $3 \mathrm{H}, \mathrm{OMe}$ ), 4.41 (dd, $1 \mathrm{H}, J$ 8.3; $9.8 \mathrm{~Hz}, \mathrm{H}-3$ '), 4.79 (dd, $\left.1 \mathrm{H}, J 1.8 ; 9.9 \mathrm{~Hz}, \mathrm{H}-5^{\prime}\right) ;{ }^{13} \mathrm{C}$ NMR (75 MHz, $\left.\mathrm{CDCl}_{3}\right): \delta-5.3\left(\mathrm{SiMe}_{2}\right),-4.5\left(\mathrm{SiMe}_{2}\right), 18.2\left(\mathrm{SiCMe}_{3}\right), 25.7\left(\mathrm{SiCMe}_{3}\right), 27.9$

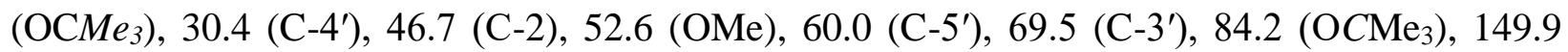
(CO), 166.9 (C-1), 171.7 (C-2'), 200.2 (C-3). Anal. Calc. for $\mathrm{C}_{19} \mathrm{H}_{33} \mathrm{NO}_{7} \mathrm{Si}$ : Calcd C 54.92, H 8.00, N 3.37; Found C 54.95, H 8.16, N 3.26; ESI-HMRS: $m / z$ calcd for $\mathrm{C}_{19} \mathrm{H}_{33} \mathrm{NO}_{7} \mathrm{NaSi}$ $[\mathrm{M}+\mathrm{Na}]^{+}:$438.1924; found: 438.1917.

Methyl (2'R,4'S)-3-(N-tert-butoxycarbonyl-4'-hydroxy-5'-oxopyrrolidin-2'-yl)-3-oxopropanoate (26). Under argon, TBAF ( $1 M$ in THF, $0.9 \mathrm{~mL}, 0.9 \mathrm{mmol}, 1.5$ equiv.) was added to a solution of 25 (263 mg, $0.6 \mathrm{mmol})$ in dry THF (22.5 mL). After stirring $2.5 \mathrm{~h}$, brine (22 mL) was added and the aqueous layer was extracted with EtOAc $(5 \times 45 \mathrm{~mL})$. The organic layers were dried, concentrated and purified by silica gel chromatography (EtOAc) to give 26 (174 mg, 91\%); $[\alpha]_{\mathrm{D}}^{25}+27(c 1.6, \mathrm{DCM}) ; \mathrm{mp} 93{ }^{\circ} \mathrm{C} ;{ }^{1} \mathrm{H} \mathrm{NMR}\left(200 \mathrm{MHz}, \mathrm{CDCl}_{3}\right): \delta 1.52\left(\mathrm{~s}, 9 \mathrm{H}, \mathrm{OCMe}_{3}\right)$, 2.22 (m, 1 H, H-4'), 2.53 (dd, 1 H, J 8.2-8.6; 13.1-13.5 Hz, H-4'), 3.58 (d, 1 H, J 16.0 Hz, H-2), 3.71 (d, $1 \mathrm{H}, J 16.0 \mathrm{~Hz}, \mathrm{H}-2), 3.78$ (s, $3 \mathrm{H}, \mathrm{OMe}$ ), 4.41 (m, $1 \mathrm{H}, \mathrm{H}-3$ '), 4.86 (dd, $1 \mathrm{H}, J 10.0 \mathrm{~Hz}$, $\left.\mathrm{H}^{-} 5^{\prime}\right) ;{ }^{13} \mathrm{C} \mathrm{NMR}\left(75 \mathrm{MHz}, \mathrm{CDCl}_{3}\right): \delta 27.7\left(\mathrm{OCMe}_{3}\right), 28.9\left(\mathrm{C}-4^{\prime}\right), 46.4(\mathrm{C}-2), 52.6(\mathrm{OMe}), 60.5$ (C-5'), 68.4 (C-3'), 84.5 (OCMe $), 149.0$ (CO), 166.7 (C-1), 173.9 (C-2'), 199.4 (C-3). Anal. Calc. for $\mathrm{C}_{13} \mathrm{H}_{19} \mathrm{NO}_{7}$ : Calcd C 51.82, H 6.36, N 4.65; Found C 51.82, H 6.46, N 4.52.

Methyl (2'R,4'S)-3-(4'-hydroxy-5'-oxopyrrolidin-2'-yl)-3-oxopropanoate (27). To a solution of 26 in DCM $(5 \mathrm{~mL})$ under argon at $0{ }^{\circ} \mathrm{C}$ was added TFA $(5 \mathrm{~mL})$. After $10 \mathrm{~min}$ of stirring at room temperature, solvents were co-evaporated with toluene. Purification by silica gel chromatography (DCM/ MeOH: 95/5) gave 27 (110 mg, 95\%); ${ }^{1} \mathrm{H}$ NMR (200 MHz, CD $\left.{ }_{3} \mathrm{OD}\right): \delta$ 2.24 (m, $\left.1 \mathrm{H}, \mathrm{H}-4^{\prime}\right), 2.53$ (m, $\left.1 \mathrm{H}, \mathrm{H}-4^{\prime}\right), 3.69-3.74$ (m, 5 H, H-2 and OMe), 4.35 (t, $1 \mathrm{H}, J$ 7.9$8.3 \mathrm{~Hz}, \mathrm{H}-3$ '), 4.44 (dd, $1 \mathrm{H}, J$ 2.4-2.6; 9.4-9.7 Hz, H-5'), $4.84($ broad s, $2 \mathrm{H}, \mathrm{NH}$ and $\mathrm{OH}) ;{ }^{13} \mathrm{C}$ NMR (50 MHz, CD 3 OD): $\delta 33.9$ (C-4'), 36.2 (C-2), 52.8 (OMe), 60.0 (C-5'), 68.9 (C-3'), 169.2 (C-1), 179.8 (C-2'), $203.4(\mathrm{C}-3)$.

Methyl (2'R,3S,4'S)-3-hydroxy-3-(4'-hydroxy-5'-oxopyrrolidin-2'-yl)propanoate (28). The protocol described for the preparation of $\mathbf{8}$ from $\mathbf{6}$, applied to 27 in the presence of $[(R)$ - 
BinapRu] $\mathrm{Br}_{2}$ at atmospheric pressure and $55^{\circ} \mathrm{C}$ during $24 \mathrm{~h}$ led to 28 after purification by silica gel chromatography (DCM/ MeOH: 9/1) (yield 98\%, d.e. 88\%); ${ }^{1} \mathrm{H}$ NMR (300 MHz, $\left.\mathrm{CD}_{3} \mathrm{OD}\right): \delta$ 2.07 (dt, 1 H, J 8.3; 13.3 Hz, H-4'), 2.33 (ddd, 1 H, J 2.3; 8.3; 13.3 Hz, H-4'), 2.41-2.57 (m, 2 H, H-2), 3.64 (ddd, 1 H, J 2.3; 3.8; 8.7 Hz, H-5'), 3.69 (s, 3 H, OMe), 3.96 (q, 1 H, J 4.1-4.5 Hz, H3), 4.39 (t, $1 \mathrm{H}, J 8.0 \mathrm{~Hz}, \mathrm{H}-3$ '), 4.85 (broad s, $3 \mathrm{H}, \mathrm{NH}$ and $\mathrm{OH}) ;{ }^{13} \mathrm{C} \mathrm{NMR}\left(75 \mathrm{MHz}, \mathrm{CD}_{3} \mathrm{OD}\right)$ : $\delta 35.2$ (C-4'), 39.7 (C-2), 52.2 (OMe), 56.8 (C-5'), 69.8 (C-3'), 71.5 (C-3), 173.4 (C-1), 180.2 $\left(\mathrm{C}-2^{\prime}\right)$.

Methyl (2'R,3R,4'S)-3-hydroxy-3-(4'-hydroxy-5'-oxopyrrolidin-2'-yl)propanoate (29). The protocol described for the preparation of $\mathbf{8}$ from $\mathbf{6}$, applied to 27 in the presence of $[(S)$ BinapRu] $\mathrm{Br}_{2}$ at atmospheric pressure and $55{ }^{\circ} \mathrm{C}$ during $88 \mathrm{~h}$ led to 29 after purification by silica gel chromatography (DCM/ MeOH: 9/1) (yield 82\%, d.e. 86\%); $[\alpha]_{\mathrm{D}}^{25}+10(c 0.4, \mathrm{MeOH}) ;{ }^{1} \mathrm{H}$ NMR (300 MHz, CD 3 OD): $\delta 1.94\left(\mathrm{dt}, 1 \mathrm{H}, J\right.$ 8.3; $\left.13.3 \mathrm{~Hz}, \mathrm{H}-4^{\prime}\right), 2.37-2.56$ (m, $3 \mathrm{H}, \mathrm{H}-2$ and H4'), 3.58 (ddd, 1 H, J 2.1; 3.8; 8.7 Hz, H-5'), 3.69 (s, 3 H, OMe), 4.00 (q, 1 H, J 4.0-4.4 Hz, H-3), 4.37 (t, $1 \mathrm{H}, J 8.1 \mathrm{~Hz}, \mathrm{H}-3$ '), 4.86 (broad s, $3 \mathrm{H}, \mathrm{NH}$ and $\mathrm{OH}) ;{ }^{13} \mathrm{C} \mathrm{NMR}\left(75 \mathrm{MHz}, \mathrm{CD}_{3} \mathrm{OD}\right)$ : $\delta 32.2$ (C-4'), 39.7 (C-2), 52.2 (OMe), 56.8 (C-5'), 69.9 (C-3'), 70.7 (C-3), 173.4 (C-1), 179.9 (C-2'). Anal. Calc. for $\mathrm{C}_{8} \mathrm{H}_{13} \mathrm{NO}_{5}$ : Calcd C 47.29, H 6.45, N 6.89; Found C 47.04, H 6.26, N 6.74 .

(1S,2'S, 4'R)-1-[5'-Oxo-4' -(triisopropylsilyloxy)pyrrolidin-2'-yl]propane-1,3-diol (30). Under argon, imidazole (145 mg, $2.1 \mathrm{mmol}, 2.6$ equiv.) and triisopropylsilyl chloride (158 mg, 0.8 mmol, 1.0 equiv.) were added to a solution of 28 (167 mg, $0.8 \mathrm{mmol})$ in dry DMF (1.3 mL). After $1.5 \mathrm{~h}$ of stirring, water $(5 \mathrm{~mL})$ was added and the aqueous layer was extracted with $\mathrm{Et}_{2} \mathrm{O}(5$ $\times 5 \mathrm{~mL}$ ). The organic layers were dried, concentrated and the crude product was purified by silica gel chromatography (EtOAc) to give the intermediate 3'-triisopropylsilyl ether which was retaken in methanol $(1.9 \mathrm{~mL})$ under argon at $0{ }^{\circ} \mathrm{C}$. Sodium borohydride $(356 \mathrm{mg}, 9.4 \mathrm{mmol}, 15.0$ equiv.) was added slowly, and the reaction mixture was stirred at room temperature during $1 \mathrm{~h}$. Aqueous $\mathrm{HCl} 1 M$ was added for reach neutral $\mathrm{pH}$, and the aqueous layer was extracted with DCM $(5 \times 10 \mathrm{~mL})$. The organic layers were dried and concentrated in vacuo. The crude was purified by silica gel chromatography (DCM/ MeOH: 9/1) to give 30 (176 mg; 65\% for the two steps); ${ }^{1} \mathrm{H}$ NMR (200 MHz, CD 3 OD): $\delta 1.11-1.12$ (m, $\left.21 \mathrm{H}, \mathrm{Si}_{i} \operatorname{Pr}_{3}\right), 1.58-1.69$ (m, $2 \mathrm{H}, \mathrm{H}-2$ ), 2.07 (m, 1 H, H-3'), 2.32 (m, 1 H, H-3'), 3.55-3.73 (m, 4 H, H-2', H-1 and H-3), 4.60 (t, 1 H, J 7.2-7.5 Hz, H-4'), 4.87 (broad s, $2 \mathrm{H}, \mathrm{NH}$ and $\mathrm{OH}$ ); ${ }^{13} \mathrm{C} \mathrm{NMR}\left(75 \mathrm{MHz}, \mathrm{CD}_{3} \mathrm{OD}\right.$ ): $\delta 13.4\left(\mathrm{Si}\left(\mathrm{CHMe}_{2}\right)_{3}\right), 18.4\left(\mathrm{Si}(\mathrm{CHMe})_{3}\right), 36.9$ (C-3'), 37.1 (C-2), 57.3, 59.7 (C-2' and C-3), 71.6, 72.1 (C-4' and C-1), 179.0 (C-5').

(2R,7S,7aS)-7-Hydroxy-2-(triisopropylsilyloxy)pyrrolizidin-3-one (31). p-Toluenesulfonyl chloride (21 mg, $0.1 \mathrm{mmol}, 1.2$ equiv.) was added to a solution of $\mathbf{3 0}$ (30 $\mathrm{mg}, 0.09 \mathrm{mmol})$ in a mixture DCM/Pyr. $(2 / 1,0.3 \mathrm{~mL})$ under argon at $0{ }^{\circ} \mathrm{C}$. After $16 \mathrm{~h}$ stirring at room temperature, the reaction mixture was poured in ice and $\mathrm{NaHCO}_{3}$ was added until neutral $\mathrm{pH}$. The overall was extracted with DCM $(4 \times 2 \mathrm{~mL})$, the organic layers were dried and concentrated to give a residue which was retaken in dry THF $(0.5 \mathrm{~mL})$ under argon. Potassium tert-butoxide $(10 \mathrm{mg}, 0.09$ mmol, 1.0 equiv.) was added and the reaction mixture was stirred $10 \mathrm{~min}$. After addition of brine 
(3 mL), extraction with DCM $(4 \times 2 \mathrm{~mL})$, drying of the organic layers, the crude was purified by silica gel chromatography to give $31(12 \mathrm{mg}, 43 \%) ;[\alpha]_{\mathrm{D}}^{25}+2\left(c 0.5, \mathrm{CHCl}_{3}\right) ;{ }^{1} \mathrm{H} \mathrm{NMR}(300 \mathrm{MHz}$, $\left.\mathrm{CDCl}_{3}\right): \delta 1.07-1.10\left(\mathrm{~m}, 21 \mathrm{H}, \mathrm{Si} i \mathrm{Pr}_{3}\right), 1.88-2.48$ (m, 4 H, H-1 and H-6), 3.17 (m, $\left.1 \mathrm{H}, \mathrm{H}-5\right), 3.61$ (m, 1 H, H-5), 3.97 (m, 1 H, H-7a), 4.11 (t, 1 H, J 3.3 Hz, H-7), 4.46 (dd, 1 H, J 2.5; 7.3 Hz, H2); ${ }^{13} \mathrm{C} \mathrm{NMR}\left(75 \mathrm{MHz}, \mathrm{CDCl}_{3}\right): \delta 12.1\left(\mathrm{Si}\left(\mathrm{CHMe}_{2}\right)_{3}\right), 17.8,17.9\left(\mathrm{Si}(\mathrm{CHMe})_{3}\right), 30.1(\mathrm{C}-1), 36.2$ (C-6), 39.3 (C-5), 64.3 (C-7a), 69.3 (C-7), 75.7 (C-2), 174.9 (C-3); ESI-HMRS: m/z calcd for $\mathrm{C}_{16} \mathrm{H}_{31} \mathrm{NO}_{3} \mathrm{NaSi}[\mathrm{M}+\mathrm{Na}]^{+}:$336.1971; found: 336.1969.

$\left(1 R, 2^{\prime} \mathbf{S}, 4^{\prime} R\right)$-1-[5'-Oxo-4' -(triisopropylsilyloxy)pyrrolidin-2'-yl]propane-1,3-diol (32). The protocol described for the preparation of 30 from 28, applied to 29, led to $32(91 \%)$; ${ }^{1} \mathrm{H}$ NMR (200 MHz, CD ${ }_{3} \mathrm{OD}$ ): $\delta$ 1.10-1.12 (m, 21 H, SiiPr 3 ), 1.49-1.65 (m, 2 H, H-2), 1.99 (m, 1 H, H-3'), 2.44 (m, 1 H, H-3'), 3.52-3.74 (m, 4 H, H-2', H-1 and H-3), 4.57 (t, 1 H, J 7.5-7.7 Hz, H-4'), 4.86 (broad s, $2 \mathrm{H}, \mathrm{NH}$ and $\mathrm{OH})$.

$(\mathbf{2 R}, 7 \boldsymbol{R}, 7 \mathrm{a} S)-7-H y d r o x y-2-(t r i i s o p r o p y l s i l y l o x y) p y r r o l i z i d i n-3-o n e \quad(33) . \quad$ The protocol described for the preparation of $\mathbf{3 1}$ from 30, applied to 32 led to $\mathbf{3 3}(20 \%) ;[\alpha]_{\mathrm{D}}^{25}-22(c 0.4$, $\mathrm{CHCl}_{3}$ ); ${ }^{1} \mathrm{H}$ NMR (300 MHz, $\left.\mathrm{CDCl}_{3}\right): \delta 1.08-1.09\left(\mathrm{~m}, 21 \mathrm{H}, \mathrm{Si} i \mathrm{Pr}_{3}\right), 1.69$ (broad s, $\left.1 \mathrm{H}, \mathrm{OH}\right)$, 1.84-2.33 (m, 4 H, H-1 and H-6), 3.28 (m, 1 H, H-5), 3.62 (m, 1 H, H-5), 3.84-4.00 (m, 2 H, H-7 and $\mathrm{H}-7 \mathrm{a}), 4.40(\mathrm{dd}, 1 \mathrm{H}, J$ 1.1-1.3; 5.9-6.1 $\mathrm{Hz}, \mathrm{H}-2) ;{ }^{13} \mathrm{C}$ NMR $\left(75 \mathrm{MHz}, \mathrm{CDCl}_{3}\right)$ : $\delta 12.1\left(\mathrm{Si}\left(\mathrm{CHMe}_{2}\right)_{3}\right), 17.8,17.9\left(\mathrm{Si}(\mathrm{CHMe})_{3}\right), 35.6,36.9$ (C-1 and C-6), $40.0(\mathrm{C}-5), 65.5(\mathrm{C}-$ 7a), 75.9 (C-2), 76.0 (C-7), 173.7 (C-3); ESI-HMRS: $m / z$ calcd for $\mathrm{C}_{16} \mathrm{H}_{31} \mathrm{NO}_{3} \mathrm{NaSi}[\mathrm{M}+\mathrm{Na}]^{+}$: 336.1971; found: 336.1977.

(2S,7R,7aS)-7-(tert-Butyldimethylsilyloxy)-2-[N,N'-di-(tert-butoxycarbonyl)hydrazino]pyrrolizidin-3-one (34). A solution of LDA was prepared under argon by adding slowly at $-40{ }^{\circ} \mathrm{C}$ a solution of $\mathrm{nBuLi} 1.6 \mathrm{M}$ in pentane $(630 \mu \mathrm{L}, 1.0 \mathrm{mmol}, 5.2$ equiv.) in a flask containing freshly distilled diisopropylamine (138 $\mu \mathrm{L}, 1.0 \mathrm{mmol}, 5.0$ equiv.) in dry THF (1.4 mL), then stirring at this temperature $45 \mathrm{~min}$. The base was then transferred slowly over a flask containing the bicyclic compound $4(50 \mathrm{mg}, 0.2 \mathrm{mmol})$ in THF $(0.3 \mathrm{~mL})$ at $-60^{\circ} \mathrm{C}$. After 3 hour of stirring, a solution of DTBAD (180 mg, $0.8 \mathrm{mmol}, 4.0$ equiv.) in THF $(0.6 \mathrm{~mL})$ was added. After one hour, the reaction mixture was quenched with aqueous saturated $\mathrm{NH}_{4} \mathrm{Cl}(10 \mathrm{~mL})$, extracted with $\mathrm{DCM}$ $(4 \times 5 \mathrm{~mL})$. The organic layers were washed with brine $(5 \mathrm{~mL})$, dried and concentrated under vacuo to give yellow oil. A purification by silica gel chromatography (EtOAc/pentane: 1/2) gave 34 (60 mg, 63\%); $[\alpha]_{\mathrm{D}}^{25}-16(c 2.4, \mathrm{DCM}) ;{ }^{1} \mathrm{H} \mathrm{NMR}\left(200 \mathrm{MHz}, \mathrm{CDCl}_{3}\right): \delta 0.06\left(\mathrm{~s}, 6 \mathrm{H}, \mathrm{Si}_{2} e_{2}\right.$ ), 0.88 (s, 9 H, $\mathrm{SiCMe}_{3}$ ), 1.46 (s, $9 \mathrm{H}, \mathrm{OCMe}_{3}$ ), 1.51 (s, $9 \mathrm{H}, \mathrm{OCMe}_{3}$ ), 1.70-1.88 (m, $2 \mathrm{H}, \mathrm{H}-1$ ), 1.97 (m, 1 H, H-6), 2.19 (m, 1 H, H-6), 2.65 (m, 1 H, H-2), 3.25 (m, 1 H, H-5), 3.50 (m, 1 H, H-7a), 3.62 (m, $1 \mathrm{H}, \mathrm{H}-5), 3.84$ (m, $1 \mathrm{H}, \mathrm{H}-7), 6.48$ (s, $1 \mathrm{H}, \mathrm{NH}) ;{ }^{13} \mathrm{C}$ NMR $\left(75 \mathrm{MHz}, \mathrm{CDCl}_{3}\right): \delta-4.8$ (SiMe $)$, -4.7 ( $\mathrm{SiMe} 2), 17.9,18.0\left(\mathrm{CMe}_{3}\right), 25.7,28.1,28.2,29.7\left(\mathrm{CMe}_{3}\right), 29.7$ (C-1), $34.8(\mathrm{C}-6)$, 35.3 (C-2), 40.2 (C-5), 63.1 (C-7 or C-7a), 65.1 (C-7 or C-7a), $81.2\left(\mathrm{CMe}_{3}\right), 154.4(\mathrm{CO}), 155.6$ (CO), 170.4 (C-3); ESI-HMRS: $m / z$ calcd for $\mathrm{C}_{23} \mathrm{H}_{43} \mathrm{~N}_{3} \mathrm{O}_{6} \mathrm{NaSi}[\mathrm{M}+\mathrm{Na}]^{+}$: 508.2819; found: 508.2810 . 


\section{Acknowledgements}

We thank Vanessa Razafimahaleo for the preparation of pyrrolizidinone $\mathbf{3}$ in the gram scale.

\section{References and Notes}

1. (a) Hanessian, S.; McNaughton-Smith, G.; Lombart, H.-G.; Lubell, W.D. Tetrahedron 1997, 53, 12789. (b) Halab, L.; Gosselin, F.; Lubell, W.D. Biopolymers (Peptide Science) 2000, $55,101$.

2. Argyropoulos, N.G.; Panagiotidis, T.; Coutouli-Argyropoulou, E.; Raptopoulou, C. Tetrahedron 2007, 63, 321.

3. Carmona, A.T.; Fuentes, J.; Vogel, P.; Robina, I. Tetrahedron: Asymmetry 2004, 15, 323.

4. Liu, X.-K.; Qiu, S.; Xiang, Y.-G.; Ruan, Y.-P. Zheng, X.; Huang, P.-Q. J Org. Chem. 2011, $76,4952$.

5. Lapointe, G.; Schenk, K.; Renaud, P. Chem. Eur. J. 2011, 17, 3207.

6. Li, Y.-J.; Chuang, H.-Y.; Yeh, S.-M.; Huang, W.-S. Eur. J. Org. Chem. 2011, 1932.

7. Despinoy, X.L.M.; McNab, H. Tetrahedron 2000, 56, 6359.

8. Hanson, G.J.; Baran, J.S.; Lindberg, T. Tetrahedron Lett. 1986, 27, 3577.

9. Miyazaki, K.; Kobayashi, M. Natsume, T.; Gondo, M.; Mikami, T.; Sakakibara, K.; Tsukagoshi, S. Chem. Pharm. Bull. 1995, 43, 1706.

10. Guerreiro, P.; Ratovelomanana-Vidal, V.; Genêt, J.-P. Chirality 2000, 408.

11. Ocejo, M.; Carrillo, L.; Vicario, J.L.; Badía, D.; Reyes, E. J. Org. Chem. 2011, 76, 460.

12. (a) Beckett, R.P.; Davies, S.G. J. Chem. Soc., Chem. Commun. 1988, 160. (b) Beckett, R.P.; Davies, S.G.; Mortlock, A.A. Tetrahedron: Asymmetry 1992, 3, 123.

13. (a) Galeotti, N.; Poncet, J.; Chiche, L.; Jouin, P. J. Org. Chem. 1993, 58, 5370. (b) Murray, A.; Proctor, G.R.; Murray, P.J. Tetrahedron Lett. 1995, 36, 291. (c) Murray, A.; Proctor, G.R.; Murray, P.J. Tetrahedron 1996, 52, 3757. (d) Schobert, R.; Wicklein, A. Synthesis, 2007, 10, 1499

14. Despinoy, X.L.M.; McNab, H. Org. Biomol. Chem. 2009, 7, 4502.

15. McNab, H.; Montgomery, J.; Parsons, S.; Tredgett, D.G. Org. Biomol. Chem. 2010, 8, 4383.

16. Shono, T.; Kise, N.; Tanabe, T. J. Org. Chem. 1988, 53, 1364.

17. Doyle, M.P.; Kalinin, A.V. Tetrahedron Lett. 1996, 37, 1371.

18. Takahata, H.; Banba, Y.; Momose, T. Tetrahedron 1991, 47, 7635.

19. (a) Tsai, Y.-M.; Nieh, H.-C.; Pan, J.-S.; Hsiao, D.-D. Chem. Commun. 1996, 2469; (b) Denmark, S. E.; Seierstad, M.; Herbert, B. J Org. Chem. 1999, 64, 884.

20. Brooks, D.W.; Lu, L.D.L.; Masamune, S. Angew. Chem. Int. Ed. Engl. 1979, 1, 72.

21. Le Bouc, G.; Thomassigny, C.; Greck, C. Heterocycles 2008, 75, 2541. 
22. (a) Gosselin, F.; Lubell, W.D. J. Org. Chem. 2000, 65, 2163. (b) Bernardi, F.; Garavelli, M.; Scatizzi, M.; Tomasini, C.; Trigari, V.; Crisma, M.; Formaggio, F.; Peggion, C.; Toniolo, C. Chem. Eur. J. 2002, 8, 2516.

23. (a) Stewart, F.H.C. J. Chem. Soc. 1963, 2099. (b) Ranganathan, S.; Ranganathan, D.; Singh, W.P. Tetrahedron Lett. 1988, 29, 3111. (c) Takahata, H.; Takamatsu, T.; Chen, Y.-S.; Ohkubo, N.; Yamazaki, T.; Momose, T.; Date T. J. Org. Chem. 1990, 55, 3792. (d) Krasnov, V.P.; Nizova, I.A.; Sinitsyna, T.A.; Avdyukova, N.V. Russian Chem. Bull. 1993, 42, 2001. (e) Javidan, A.; Schafer, K.; Pyne, S.G. Synlett 1997, 100. (f) Avenoza, A.; Cativiela, C.; Peregrina, J.M.; Zurbano, M.M. Tetrahedron: Asymmetry 1997, 8, 863. (g) Tanaka, K.-I.; Sawanishi, H. Tetrahedron: Asymmetry 2000, 11, 3837. (h) Krasnov, V.P.; Vigorov, A. Y.; Nizova, I. A.; Matveeva, T. V.; Grishakov, A. N.; Bazhov, I. V.; Tumashov, A. A.; Ezhikova, M. A.; Kodess, M. I. Eur. J. Org. Chem. 2007, 4257. (i) Vaswani, R.G.; Chamberlin, A.R. J. Org. Chem. 2008, 73, 1661.

24. (a) Goswami, R.; Moloney, M. G. Chem. Commun. 1999, 2333. (b) Bentz, E. L.; Goswami, R.; Moloney, M. G.; Westaway, S. M. Org. Biomol. Chem. 2005, 3, 2872.

25. (a) Boyd, D.B.; Foster, B.J.; Hatfield, L.D.; Hornback, W.J.; Jones, N.D.; Munroe, J.E.; Swartzendruber, J.K. Tetrahedron Lett. 1986, 27, 3457. (b) Allen, N.E.; Boyd, D.B.; Campbell, J.B.; Deeter, J.B.; Elzey, T.K.; Foster, B.J.; Hatfield, L.D.; Hobbs, Jr, J.N.; Hornback, W.J.; Hunden, D.C.; Jones, N.D.; Kinnick, M.D.; Morin, Jr, J.M.; Munroe, J.E.; Swartzendruber, J.K.; Vogt, D.G. Tetrahedron 1989, 45, 1905. (c) Skof, M.; Svete, J.; Kmetic, M.; Golic-Grdadolnik, S.; Stanovnik, B. Eur. J. Org. Chem. 1999, 1581.

26. (a) Saijo, S.; Wada, M.; Himizu, J.-I.; Ishida, A. Chem. Pharm. Bull. 1980, 28, 1449. (b) Katoh, T.; Nagata, Y.; Kobayashi, Y.; Arai, K.; Minami, J.; Terashima, S. Tetrahedron 1994, 50, 6221.

27. Ohta, T.; Hosoi, A.; Nozoe, S. Tetrahedron Lett. 1988, 29, 329.

28. Avent, A.G.; Bowler, A.N.; Doyle, P.M.; Marchand, C.M., Young, D.W. Tetrahedron Lett. 1992, 33, 1509.

29. Genêt, J.P.; Ratovelomanana-Vidal, V.; Caño de Andrade, M.C.; Pfister, X.; Guerreiro, P.; Lenoir, J.Y. Tetrahedron Lett. 1995, 36, 4801.

30. Harris, B.D.; Bhat, K.L.; Joullié, M.M. Heterocycles 1986, 24, 1045. 